\title{
Radar-based characterisation of heavy precipitation in the eastern Mediterranean and its representation in a convection-permitting model
}

\author{
Moshe Armon $^{1}$, Francesco Marra ${ }^{1,2}$, Yehouda Enzel ${ }^{1}$, Dorita Rostkier-Edelstein ${ }^{1,3}$, and Efrat Morin ${ }^{1}$ \\ ${ }^{1}$ Fredy and Nadine Herrmann Institute of Earth Sciences, the Hebrew University of Jerusalem, \\ Edmond J. Safra Campus, Jerusalem 9190401, Israel \\ ${ }^{2}$ National Research Council of Italy, Institute of Atmospheric Sciences and Climate, CNR-ISAC, Bologna 40129, Italy \\ ${ }^{3}$ Department of Applied Mathematics, Environmental Sciences Division, IIBR, Ness-Ziona 7410001, Israel
}

Correspondence: Moshe Armon (moshe.armon@mail.huji.ac.il)

Received: 25 September 2019 - Discussion started: 7 October 2019

Revised: 28 January 2020 - Accepted: 2 February 2020 - Published: 16 March 2020

\begin{abstract}
Heavy precipitation events (HPEs) can lead to natural hazards (e.g. floods and debris flows) and contribute to water resources. Spatiotemporal rainfall patterns govern the hydrological, geomorphological, and societal effects of HPEs. Thus, a correct characterisation and prediction of rainfall patterns is crucial for coping with these events. Information from rain gauges is generally limited due to the sparseness of the networks, especially in the presence of sharp climatic gradients. Forecasting HPEs depends on the ability of weather models to generate credible rainfall patterns. This paper characterises rainfall patterns during HPEs based on high-resolution weather radar data and evaluates the performance of a high-resolution, convection-permitting Weather Research and Forecasting (WRF) model in simulating these patterns. We identified 41 HPEs in the eastern Mediterranean from a 24-year radar record using local thresholds based on quantiles for different durations, classified these events into two synoptic systems, and ran model simulations for them. For most durations, HPEs near the coastline were characterised by the highest rain intensities; however, for short durations, the highest rain intensities were found for the inland desert. During the rainy season, the rain field's centre of mass progresses from the sea inland. Rainfall during HPEs is highly localised in both space (less than a $10 \mathrm{~km}$ decorrelation distance) and time (less than $5 \mathrm{~min}$ ). WRF model simulations were accurate in generating the structure and location of the rain fields in 39 out of 41 HPEs. However, they showed a positive bias relative to the radar estimates and exhibited er-
\end{abstract}

rors in the spatial location of the heaviest precipitation. Our results indicate that convection-permitting model outputs can provide reliable climatological analyses of heavy precipitation patterns; conversely, flood forecasting requires the use of ensemble simulations to overcome the spatial location errors.

\section{Introduction}

Heavy precipitation events (HPEs) cause natural hazards such as flash, riverine, and urban floods as well as landslides and debris flows; they also serve as a resource for recharging groundwater and surface water reservoirs (e.g. Bogaard and Greco, 2016; Borga et al., 2014; Borga and Morin, 2014; Doswell et al., 1996; Nasta et al., 2018; RavehRubin and Wernli, 2015; Samuels et al., 2009; Taylor et al., 2013; UN-Habitat, 2011). Diverse rainfall patterns during HPEs cause different hydrological responses; thus, an accurate representation of rainfall patterns during these events is crucial for detecting and predicting climate-change-induced precipitation changes (Maraun et al., 2010; Trenberth et al., 2003). In particular, understanding the specific interactions between rainstorms and catchments is critical in small watersheds, where accurate, high spatiotemporal resolution observations and forecasts are required (e.g. Bloschl and Sivapalan, 1995; Cristiano et al., 2017). However, these data may not be available through operational tools, such as rain gauge 
networks and coarse-scale weather models (e.g. commonly used, global or even regional circulation models). Thus, highresolution observation and HPE forecasts remain a challenge (Borga et al., 2011; Collier, 2007; Doswell et al., 1996).

Rain gauge data can be used to quantify general characteristics of HPEs (such as rain intensity and depth on a point scale), but their density is generally insufficient to adequately represent the spatial gradients, particularly in the case of sparsely gauged regions, short-lived events, and arid climates (Amponsah et al., 2018; Kidd et al., 2017; Morin et al., 2009, 2020). This problem is enhanced in regions characterised by high climatic gradients such as the eastern Mediterranean, hereafter referred to as "EM" (El-Samra et al., 2018; Marra et al., 2017; Marra and Morin, 2015; Morin et al., 2007; Rostkier-Edelstein et al., 2014). Thus, a high-resolution characterisation of HPEs in such regions must be supported by other types of records. Remotely sensed precipitation estimates, such as those acquired from weather radars, provide the necessary spatiotemporal resolutions (e.g. $1 \mathrm{~km}$ and $5 \mathrm{~min}$ ) and coverage (regional scale) and have been shown to be useful for analysing specific events (e.g. Borga et al., 2007; Dayan et al., 2001; Krichak et al., 2000; Smith et al., 2001). Where continuous radar records exist, they have been used in climatological studies as well (Belachsen et al., 2017; Bližňák et al., 2018; Peleg and Morin, 2012; Saltikoff et al., 2019; Smith et al., 2012). However, climatological characterisations of rainfall patterns during HPEs are rare in the literature and often based on rain gauge identification of those events (Panziera et al., 2018; Thorndahl et al., 2014).

High-resolution numerical weather prediction (NWP) models allow for the simulation and forecasting of HPEs, and, as added value, they enable an understanding of their past and present patterns to be developed as well as a prediction of possible future behaviours (Cassola et al., 2015; Deng et al., 2015; El-Samra et al., 2018; Kendon et al., 2014; Prein et al., 2015; Rostkier-Edelstein et al., 2014; Yang et al., 2014). In particular, convection-permitting models are increasingly used in weather forecasts, climatological studies, and event-based reanalyses (e.g. Ban et al., 2014; Fosser et al., 2014; Hahmann et al., 2010; Khodayar et al., 2016; Prein et al., 2015; Rostkier-Edelstein et al., 2015). Such models downscale global or regional NWP models and provide a direct representation of convective rainfall that, due to its high intensity and local characteristics, often plays a major role in HPEs (e.g. Flaounas et al., 2018). In addition, these models can provide 3-D fields of otherwise unmeasurable meteorological variables, thereby contributing to our understanding of the dynamics of HPEs. Studies based on high-resolution NWP models commonly focus on specific cases. For example, Zittis et al. (2017) examined the performance of a high-resolution NWP model during five HPEs in the EM and identified large discrepancies between grid- and gauge-based precipitation datasets, making it hard to validate the model. Only a few studies have examined the climatology of model results, with the aim of either determin- ing the atmospheric conditions that trigger HPEs or understanding the overall rainfall pattern in comparison to observational records (e.g. Flaounas et al., 2019; Kendon et al., 2014; Khodayar et al., 2018). Commonly, climate change studies based on high-resolution NWP models characterise the expected changes in precipitation, focusing on rainfall intensity or frequency, or some derived index (e.g. Ban et al., 2014; Hochman et al., 2018b; Schär et al., 2016; Westra et al., 2014).

A basic question, however, remains open: to what degree is the model description of rainfall during HPEs credible? Moreover, the model's ability to reproduce rainfall patterns can differ among synoptic types. To answer this question, both a realistic spatiotemporal representation of rainfall during HPEs and a large number of observed HPEs, triggered by various synoptic systems, are necessary. In this paper, we present a successful step in this direction based on a corrected and calibrated 24-year-long record of weather radar data recently developed for the EM, which has been found to adequately represent extreme precipitation events (Marra and Morin, 2015). As an essential step in understanding and quantifying rainfall-generating processes involved in HPEs and as a basis for a future study that will include downscaling of climate change projections to understand changes in rainfall patterns, here we aim to (i) characterise high-resolution rainfall patterns (seasonality, spatial distribution of intensities, location, and spatiotemporal structure) during HPEs in the hydroclimatically heterogeneous EM and (ii) assess the capabilities of a regional convection-permitting weather model to simulate these patterns. To this aim, we identified all HPEs embedded in the radar record (41 events) and simulated them using a convection-permitting Weather Research and Forecasting (WRF) model (Skamarock et al., 2008). This long and consistent high-resolution dataset is unique; thus, it is interesting both for examining HPE climatology and as a basis for convection-permitting model evaluation. Considering that our observations are based on radar data, they are certainly not perfect. Therefore, we quantified and compared several rainfall characteristics from both radar estimates and simulated rainfall to evaluate the model's ability to reproduce the rainfall patterns and to obtain climatological characteristics of HPEs.

The paper is structured as follows: Sect. 2 describes the study region; the radar and weather model data are explained in Sect. 3.1 and 3.2, respectively; identification and synoptic classification of HPEs are presented in Sect. 3.3 and 3.4, respectively; the methods used to evaluate model performance are presented in Sect. 3.5; Sect. 4 presents the results of the evaluation and characterisation of rainfall patterns during HPEs; Sect. 5 provides a discussion; and Sect. 6 concludes. 


\section{Study region}

This study focuses on the EM region, where Mediterranean climate (which can reach a mean annual precipitation of more than $1000 \mathrm{~mm} \mathrm{yr}^{-1}$ ) drops to hyperarid (less than $50 \mathrm{~mm} \mathrm{yr}^{-1}$ ) over a short distance (Goldreich, 2012) (Fig. 1). Precipitation is dominated by rainfall, and it mainly occurs between October and May, with summer months (June to September) being essentially dry (Kushnir et al., 2017). Most of this rainfall is associated with cold north-westerly flows in the rear part of Mediterranean cyclones (MCs). These MCs pass above the warm water of the Mediterranean Sea, absorbing moisture and precipitating it over the EM region (Alpert et al., 2004; Alpert and Shay-EL, 1994; Armon et al., 2019; Saaroni et al., 2010; Ziv et al., 2015). High surface water temperature favours high-intensity rainfall and floods, most commonly at the beginning of the rainy season and near the sea. As the MCs move inland and towards the desert, a substantial amount of the moisture is lost, and rainfall occurrence and amounts are greatly reduced (Enzel et al., 2008). In this arid region, HPEs are associated not only with MCs (Kahana et al., 2002) but also with active Red Sea troughs (ARSTs) (Ashbel, 1938; Krichak et al., 1997; De Vries et al., 2013) and, more rarely, with tropical plumes (Armon et al., 2018; Rubin et al., 2007; Tubi et al., 2017). Commonly, rainfall during ARSTs is of a spotty nature, can reach far into the desert, and can be of very high intensity (Armon et al., 2018; Sharon, 1972). Conversely, during tropical plumes, rainfall is widespread, potentially covering most of the region simultaneously with moderate intensities. Desert HPEs frequently result in large and sometimes devastating flash floods (e.g. Armon et al., 2018; Dayan and Morin, 2006; Farhan and Anbar, 2014; Kahana et al., 2002; Saaroni et al., 2014; Seager et al., 2014). Projections for precipitation in the EM indicate a substantial decrease in annual rainfall amounts (Giorgi and Lionello, 2008). However, the importance of credible HPE simulations stems from, among others, opposing trends that may appear between the number and intensity of HPEs generated by different synoptic conditions (Alpert et al., 2002; Hochman et al., 2018b, 2020; Marra et al., 2019); for example, based on Dead Sea sedimentological data, it has been suggested that when MC frequency is reduced, i.e. there is a regional drought, the frequency of HPEs generated by ARSTs may increase (Ahlborn et al., 2018).

\section{Methodology and data}

\subsection{Weather radar data}

The weather radar data used in this study consist of 24 hydrological years (September-August), between 1990-1991 and 2013-2014, observed by the Electrical Mechanical Services (EMS/Shacham) non-Doppler C-band weather radar (5.35 cm wavelength), located at Ben Gurion Airport (Fig. 1; $\left.31.998^{\circ} \mathrm{N}, 34.908^{\circ} \mathrm{E}\right)$. Its effective range is $185 \mathrm{~km}$. Raw radar reflectivity data were translated to quantitative precipitation estimates (QPEs) using a fixed Z-R relationship $\left(Z=316 \cdot R^{1.5}\right)$ and applying physically based corrections and gauge-based adjustment procedures (see details in Marra and Morin, 2015). This produced QPEs at $1 \mathrm{~km}^{2}$ and roughly 5 min resolutions. Examining the radar QPE and comparing it with rain gauges at an hourly and yearly resolution yielded a root-mean-square error of $1.4-3.2 \mathrm{~mm} \mathrm{~h}^{-1}$ and 13 $220 \mathrm{~mm} \mathrm{yr}^{-1}$, respectively, and a bias of 0.8-1.1 (hourly) and 0.9-1.1 (yearly) (Marra and Morin, 2015). This archive has previously been used for a series of studies focusing on high-intensity precipitation, including precipitation frequency analysis (Marra et al., 2017; Marra and Morin, 2015), floods (Rinat et al., 2018; Zoccatelli et al., 2019), and characterisation of convective rain cells (Belachsen et al., 2017; Peleg et al., 2018). A few of the following issues potentially affecting the QPE should be mentioned. The radar was turned off during the dry season and, for technical reasons, sometimes during the wet season; thus, a few severe storms were missed and are not included in the archive. A long-term decline in the availability and quality of radar data might have decreased the number of high-quality archived HPEs over the years, mainly since 2010 . As we did not aim to provide a complete climatology, these aspects were not expected to influence the results of the study. For technical reasons, the radar products were not always available at their intended temporal resolution (approximately $5 \mathrm{~min}$ ) and longer gaps may exist between consecutive radar scans. Gaps of less than 20 min between consecutive radar scans were linearly interpolated to recreate the $5 \mathrm{~min}$ resolution; gaps of more than 20 min were treated as missing data. Due to the uneven spatial distribution of the rain gauges, adjustment procedures may inadequately represent the south-easternmost areas covered by the radar, where the gauge network is most sparse. Finally, due to overshooting of the radar beam, precipitation occurring east of the Dead Sea (Fig. 1) is generally underestimated.

\subsection{WRF model configuration}

The WRF model was configured using three two-way nested domains, with a $1: 5$ resolution ratio between them (Fig. 1) and 68 vertical levels (model top is at $25 \mathrm{hPa}$ ). The inner domain (551 pixels $\times 551$ pixels) was set at a $1 \mathrm{~km}^{2}$ horizontal resolution, in order to be comparable with the radar data. To comply with the Courant-Friedrichs-Lewy numerical stability criterion, model time steps in the innermost domain were between 4 and $8 \mathrm{~s}$ (Warner, 2011). However, to spare computer storage, outputs were saved at $10 \mathrm{~min}$ intervals. When analysed, the WRF grid was interpolated using nearest-neighbour interpolation from a Lambert projection grid to a similar-sized grid on a transverse Mercator projection, as in the radar archive. It is important to note that a $1 \mathrm{~km}^{2}$ spatial resolution enables the explicit res- 

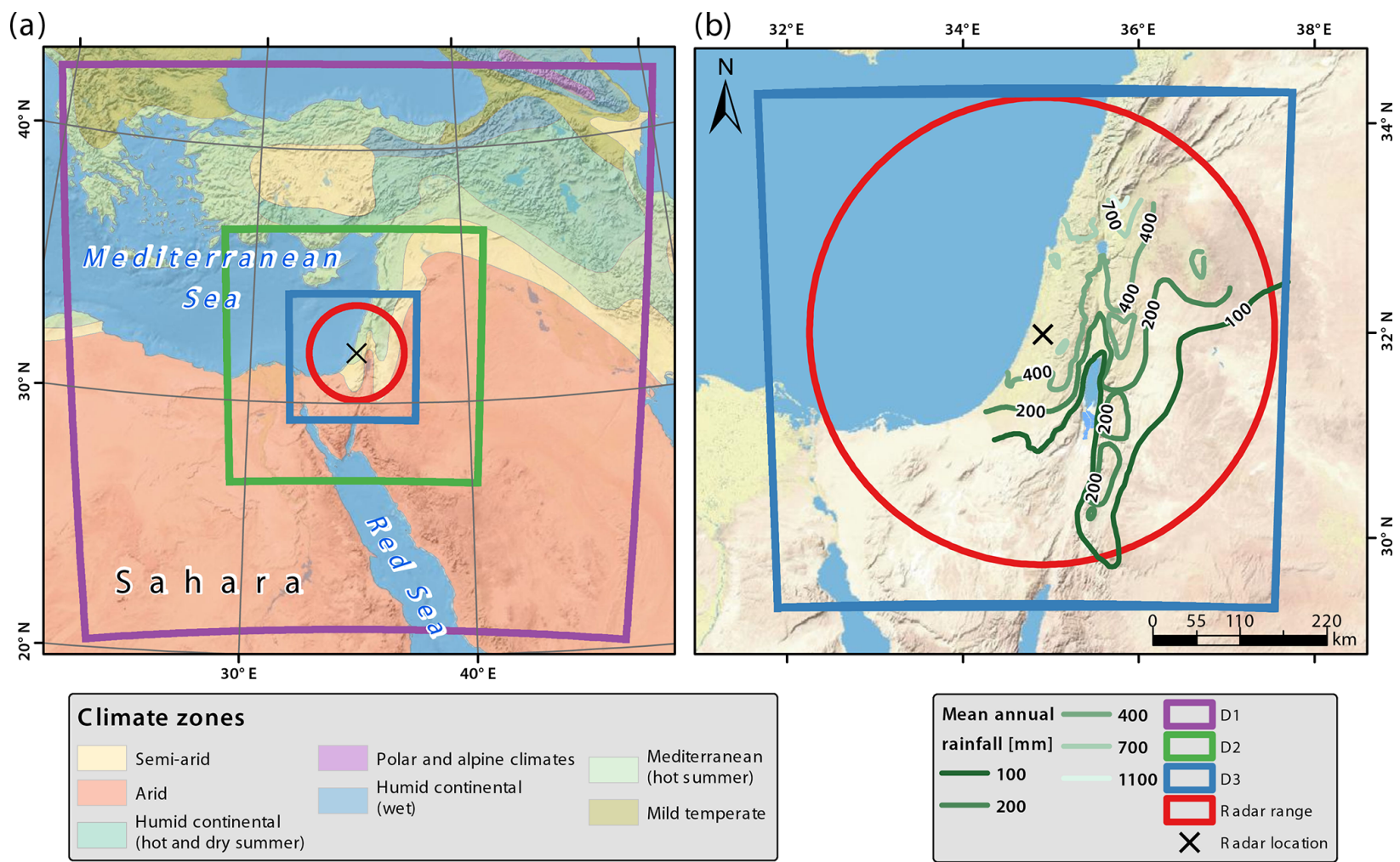

Figure 1. Study region. (a) Climate zones in the eastern Mediterranean, three nested domains used in the weather model (D1-3; purple, green, and blue) and the radar domain (red). (b) Mean annual rainfall isohyets, radar, and innermost model domains. Climatic classification is from the Atlas of Israel (2011). Basemap source: U.S. National Park Service.

olution of convection, without the use of parameterisation (e.g. Prein et al., 2015). The two outer domains used the WRF Tiedtke scheme for the parameterisation of convection (Tiedtke, 1989; C. Zhang et al., 2011). The model input data were 6-hourly ERA-Interim reanalyses, at approximately an $80 \mathrm{~km}$ horizontal resolution, and with 60 vertical levels, including sea surface temperature, along with basic meteorological parameters (Dee et al., 2011). The model was used to simulate the HPEs identified in the radar archive (Sect. 3.3; Table S1 in the Supplement). Each simulation started $24 \mathrm{~h}$ prior to the beginning of the event, rounded down to the previous $6 \mathrm{~h}$, and finished at the end of the HPE, rounded up to the next $6 \mathrm{~h}$. Therefore, the spin-up period of each simulation was at least $24 \mathrm{~h}$. Additional model settings, presented in Table 1 , were selected because they are considered suitable for convection-permitting simulations (e.g. Romine et al., 2013; Schwartz et al., 2015).

\subsection{HPE identification}

HPEs have various definitions in different research fields and geographical regions. For example, climatologically, HPEs are commonly associated with a specific time interval (i.e. sub-daily to a number of consecutive days) during which precipitation depth surpasses a threshold representing a prede- fined quantile (e.g. 95th or 99th) or a high but constant intensity (e.g. 10, 20, or $50 \mathrm{~mm} \mathrm{~d}^{-1}$; see Drobinski et al., 2014; Nuissier et al., 2011; Westra et al., 2014; X. Zhang et al., 2011). In contrast, hydrological definitions usually focus on the resulting flood. In general, a good definition of a HPE should also include the areal dimension to enable hydrological and social impacts to be taken into account (Easterling et al., 2000).

Here we define HPEs by the exceedance of local, quantilebased thresholds over a sufficiently large area. The decision to set local thresholds was due to the sharp climatic gradient characterising the study area. To decrease the computational effort and guarantee adequate temporal sampling, the HPE identification was based on a radar database comprising hourly intervals for which at least $60 \%$ of the expected radar scans were available (Marra et al., 2017). For a set of durations between 1 and $72 \mathrm{~h}$, we defined the threshold as the 99.5th quantile of the non-zero (i.e. more than $0.1 \mathrm{~mm}$ ) hourly amounts observed in each radar pixel. The range of examined durations was chosen to represent both short- and long-lived HPEs. It should be noted that the same storm can be identified as a HPE for multiple durations. Depending on the duration and location, the amounts obtained are equivalent to annual return periods of roughly 2-10 years (Fig. 2). To account for the spatial scale, we classified all time inter- 
Table 1. WRF model settings and specifications.

\begin{tabular}{llll}
\hline & Outer nest & Middle nest & Inner nest \\
\hline Domains & & & \\
\hline Spatial resolution (km) & $25 \times 25$ & $5 \times 5$ & $1 \times 1$ \\
Temporal resolution (s) & $\sim 100$ & $\sim 20$ & $4-8$ \\
Domain size (pixels) & $100 \times 100$ & $221 \times 221$ & $551 \times 551$ \\
Number of vertical layers & 68 & 68 & 68 \\
Model top (hPa) & 25 & 25 & 25 \\
\hline
\end{tabular}

\begin{tabular}{l}
\hline Physics \\
\hline Cumulus scheme (outer and middle nests only) \\
Microphysical scheme \\
Radiative transfer scheme \\
Planetary boundary layer scheme \\
Surface layer scheme \\
Land surface model
\end{tabular}

Tiedtke (Tiedtke, 1989; C. Zhang et al., 2011)

Thompson (Thompson et al., 2008)

RRTMG short wave and long wave (Iacono et al., 2008)

Mellor-Yamada-Janjić (Janjić, 1994)

Land surface model

Eta similarity scheme (Janjić, 1994)

Unified Noah land surface (Tewari et al., 2004)
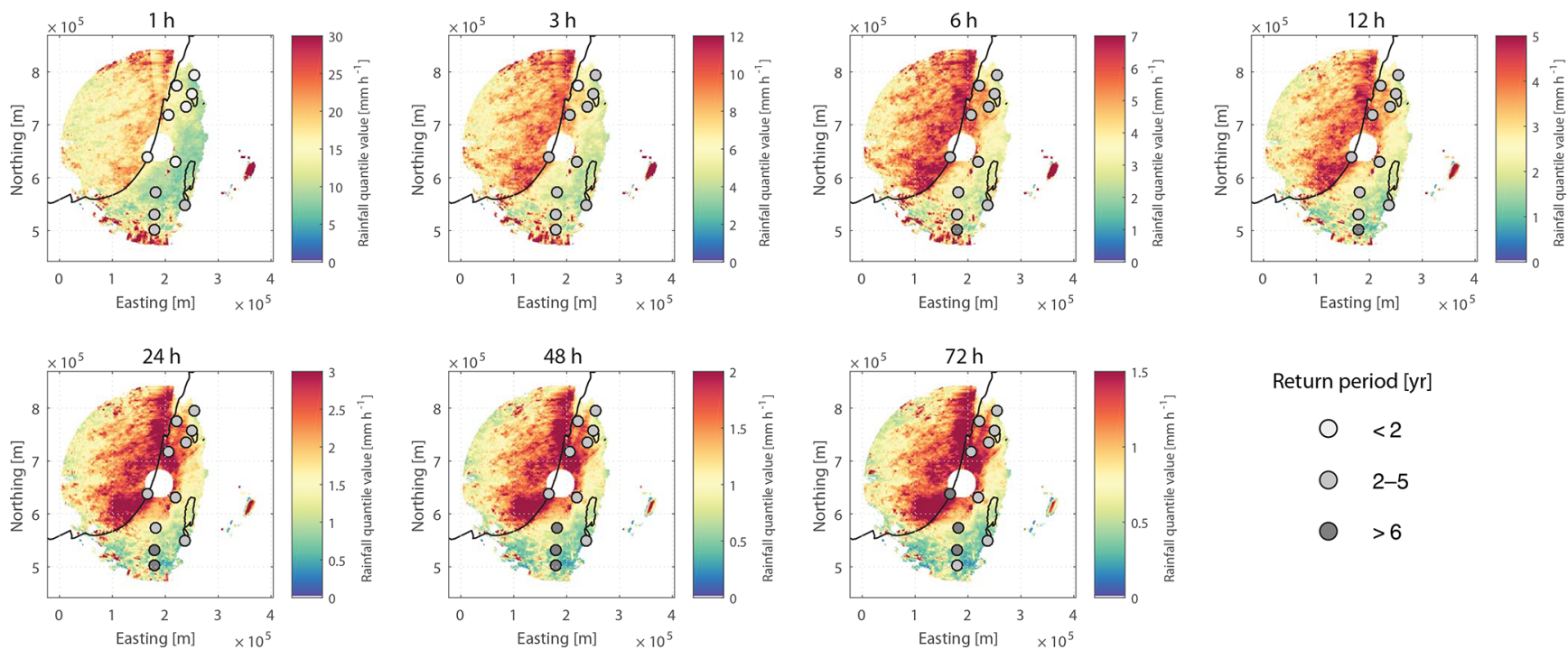

Return period $[y r]$

$\bigcirc<2$

○ $2-5$

$\bigcirc>6$

Figure 2. The $99.5 \%$ rain intensity quantile of each radar pixel for durations of $1 \mathrm{~h}$ (top-left panel) to $72 \mathrm{~h}$ (bottom-right panel). Notice the change in the colour scale between different durations. Also shown are annual return periods of the rain-intensity threshold averaged over nine pixels around 11 locations (generalised extreme value fit of the rain gauge annual maxima series, using the method of probabilityweighted moments, with records of at least 44 years). These computed annual return periods range between 1.8 and 10.4 years. White areas found mostly to the east of the radar were masked out according to the black line in Fig. 6c (Sect. 4.2).

vals during which at least 1000 pixels (i.e. $1000 \mathrm{~km}^{2}$ ) exceed their local threshold as HPEs. Jointly, these thresholds (99.5\% for each pixel, and an aggregation of 1000 pixels for an event) settle the trade-off between having too many (or too few) events and accounting for HPEs that are too local (or only including the most widespread rainstorms). These selected thresholds enable the analysis of a reasonable number of diverse HPEs, with some being quite local and others more widespread.

The selection procedure yielded 76-98 individual events for each of the examined durations, summing to 120 when overlaps between durations were included. Similar to Marra and Morin (2015), storms were separated by at least $24 \mathrm{~h}$ with less than 100 pixels displaying rainfall of more than $0.1 \mathrm{~mm}$. As the ERA-Interim data are available at a $6 \mathrm{~h}$ resolution, rainstorms that were too short (less than $12 \mathrm{~h}$ ) were excluded from the analysis. Storms longer than $144 \mathrm{~h}$ were excluded to avoid major changes in sea surface temperature during events. In addition, events were discarded manually when the radar data were abundantly contaminated by ground clutter due to anomalous propagation or when other data-quality issues were observed. The final list of HPEs consisted of 41 independent events spanning $3.4 \pm 1.6 \mathrm{~d}$ on average (Table S1). 
For each of these events, a filter was used to remove pixels with residual ground clutter. Pixels in which the probability of rain detection (POD, i.e. the fraction of time in which the pixel exceeds $0.1 \mathrm{mmh}^{-1}$ ) exceeds $10 \%$ and is larger than 1.9 times the average POD of the surrounding area $(25 \mathrm{~km} \times 25 \mathrm{~km})$ were removed. The extent of the explored area and of the ratio were chosen subjectively after examining ranges between 1 and 3 (for the ratio) and 5 and $50 \mathrm{~km}$ (for the areal extent). Additional areas known to be persistently contaminated by ground echoes (from our experience and earlier studies) were masked out manually (e.g. the circular area near the radar). Together, these procedures excluded approximately $0.5 \%$ of the radar pixels.

\subsection{Synoptic classification}

We classified the HPEs into two classes representing the most common rainy synoptic circulation patterns prevailing in the region: MC and ARST. To do so, we relied on the semi-objective synoptic classification by Alpert et al. (2004), based on daily (at 12:00 UTC) meteorological fields at the $1000 \mathrm{hPa}$ pressure level from the NCEP/NCAR reanalysis (2.5 $5^{\circ}$ spatial resolution). We classified a HPE as a MC if one of the following conditions occurred: (i) most of the days comprising the HPE were considered, according to Alpert et al. (2004), as days with either a MC or a high-pressure system following a MC; (ii) one of the days during the HPE was a MC and none of them were an ARST. Similarly, we classified a HPE as an ARST if (i) most of its days were classified as ARST according to Alpert et al. (2004) or (ii) one of its days was an ARST and none of them were a MC. The above-mentioned tropical plume synoptic pattern (Rubin et al., 2007; Tubi et al., 2017) is not part of our classification because of its low frequency and because it does not appear in near-sea-level pressure meteorological fields. Specifically, one HPE (HPE 41; Table S1) was characterised, during its $5 \mathrm{~d}$ span, first by the prevalence of a tropical plume (Armon et al., 2018) and then by a MC; it was classified here as a MC. Despite the simplification, these two classes have recently been shown to exhibit distinct characteristics of rainfall intensity distribution (Marra et al., 2019). Indeed, $85 \%$ and $15 \%$ of HPEs were classified as MCs and ARSTs, respectively (Table S1), reasonably following the expected proportions of the two synoptic circulation patterns (Goldreich et al., 2004; Saaroni et al., 2010).

\subsection{Evaluation of simulated rain fields}

Inaccurate initial conditions in the presence of non-linear precipitation-generation processes, along with the presence of atmospheric instabilities, may limit the atmospheric predictability and, consequently, modelling skill (Anthes et al., 1985). Moreover, increasing the model resolution may pose difficulties in a pixel-by-pixel evaluation of the forecasts (e.g. Davis et al., 2006; Mass et al., 2002). Approaches that are more suitable for high-resolution rainfall fields range from simple visual comparisons to more sophisticated, objectoriented or filtering methods capable of representing spatiotemporal properties of the fields (e.g. Davis et al., 2006; Gilleland et al., 2009; Roberts and Lean, 2008). In this study, we applied visual comparisons and several numerical measures to compare the observed radar QPE with the WRFderived rain field.

\subsubsection{Fractions skill score}

To evaluate rainfall accumulation for different neighbourhood sizes (namely, spatial scales), we used the method suggested by Roberts and Lean (2008). The methodology includes a conversion of the continuous rain field to a binary field based on the exceedance of a given rain-depth threshold. The fraction of model-output positive pixels (i.e. pixels that have exceeded the threshold) within a certain neighbourhood size is then compared with the matching fraction from the radar QPE, via the fractions skill score (FSS) statistic (Sect. S1 in the Supplement). When the forecast is perfect and unbiased, i.e. when an equal number of observed (in our case, radar) and forecasted (WRF) pixels exceed the threshold, the FSS is equal to 1 . If there is a bias, the FSS will tend asymptotically to a lower value. To quantitatively evaluate the model's ability to predict the observed rainfall above the selected threshold, within a close-enough distance, the uniform FSS (halfway between a random forecast and a perfect skill forecast, yielding a hit rate of 0.5 ; Sect. S1) is also calculated. A FSS that is larger than the uniform FSS is considered skilful. It is important to note that if the FSS exceeds the uniform FSS on too large a spatial scale, the forecast might still be skilful, but it is not useful. We applied the FSS method to the cumulative rain field, comparing the radar QPEs and WRF rainfall output (Sect. 4.3).

\subsubsection{Structure-amplitude-location analysis}

To evaluate the characteristics of the WRF precipitation forecast errors, we used the object-oriented structure-amplitudelocation (SAL) analysis (Wernli et al., 2008) (Sect. S2 in the Supplement). As in the FSS analysis, it was applied to the cumulative rain field. The SAL analysis splits the rain field into three distinct components and yields a skill score for the forecast of each of them; in each of the components, a zero score indicates a perfect forecast. The amplitude component $(A)$ expresses the model's over- or underestimation of the total rainfall for a specific rainstorm (with $A \in[-2,2]$, and $A=1$ or $A=-1$ indicating over- and underestimation by a factor of 3 , respectively). The location component $(L \in[0,2])$ sums the differences between modelled and observed (i) centre of mass of precipitation and (ii) average distance between the centre of mass and the location of precipitation objects that constitute the rain field (i.e. connected regions in which the cumulative rainfall exceeds $1 / 15$ of the maximal cumu- 
lated value; Wernli et al., 2008). The structure component $(S \in[-2,2])$ quantifies the tendency of the forecasted precipitation objects to be either too smooth (positive values) or too noisy (negative values) relative to the observations.

\subsubsection{Depth-area-duration curves}

Areal rainfall amounts are crucial drivers of the hydrological response and are important for understanding rainfall structure and triggering mechanisms (e.g. Armon et al., 2018; Durrans et al., 2002; Kalma and Franks, 2003; Zepeda-Arce et al., 2000). To quantify and compare observed and simulated areal rainfall amounts, we used depth-area-duration (DAD) curves, which represent the areal extent for which given rainfall depths over specific durations are exceeded (Zepeda-Arce et al., 2000).

\subsubsection{Autocorrelation structure of rain fields}

High-intensity, small-scale convective rain cells are among the main factors generating flash floods in small, mountainous and desert catchments (e.g. Armon et al., 2018; Doswell et al., 1996; Merz and Blöschl, 2003), and their fine spatiotemporal structure directly affects the potential of rain gauge monitoring (Marra and Morin, 2018). To analyse the convective rain structure, we computed the spatial autocorrelation structure of the maps containing convective elements from both the observed radar QPE and the WRF output using the methodology presented by Marra and Morin (2018) (an example is given in Fig. S1). We interpolated the radar QPEs to 10 min intervals to match the model's temporal resolution, and defined all rain maps in which at least one convective rain cell (defined as a connected region $\geq 3 \mathrm{~km}^{2}$ with rain intensity exceeding $10 \mathrm{~mm} \mathrm{~h}^{-1}$ and including at least one pixel exceeding $25 \mathrm{~mm} \mathrm{~h}^{-1}$ ) is observed as convective rainfall fields (Marra and Morin, 2018). We computed the 2-D spatial autocorrelation function of the convective fields following the method in Nerini et al. (2017). A three-parameter exponential function (Eq. 1) was fitted to the 2-D spatial autocorrelation to quantify the correlation distance:

$$
r(h)=a e^{-\left(\frac{h}{b}\right)^{c}}
$$

where $h$ is the lag distance, $b$ is the correlation distance (the distance at which the correlation drops to $r=e^{-1}$ ), and $a$ and $c$ are the nugget and shape parameters of the curve, respectively. Equation (1) results in an approximation of the 1-D autocorrelation function of convective rain fields. The spatial heterogeneity of the autocorrelation field is quantified by calculating the deviation of the 2-D autocorrelation field from isotropy, following the approach in Marra and Morin (2018). To this end, we defined the ellipticity of the 2-D autocorrelation as the ratio of the minor to major axis of the (approximated) ellipse encompassing the $r=e^{-1}$ region of the spatial autocorrelation field (Fig. S1).

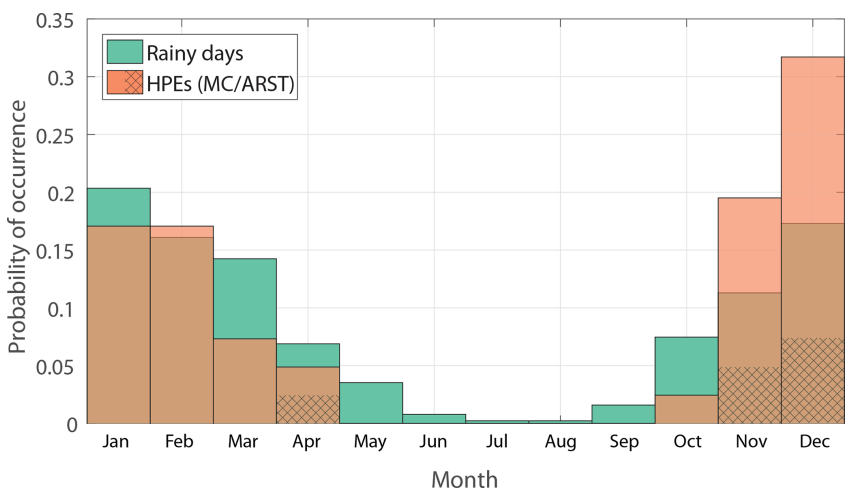

Figure 3. Monthly probability of occurrence of rainy days near the radar location (green; Bet Dagan rain gauge; $32.0^{\circ} \mathrm{N}, 34.8^{\circ} \mathrm{E}$ ), and of HPEs from the radar archive (orange). Hatching represents HPEs classified as ARSTs.

The temporal autocorrelation is computed by converting the 2-D spatial domain to a 1-D array and adopting time as the second dimension, as proposed by Marra and Morin (2018). It is worth noting that the computed temporal correlation distance neglects advection (Eulerian perspective) and is therefore shorter than the correlation distance obtained in a Lagrangian perspective.

\section{Results}

\subsection{Quasi-climatology of HPEs}

Of the 41 identified HPEs, 35 occurred during MC synoptic prevalence and the rest during ARST prevalence. Despite the dependence of the identification on the quality and availability of the radar data, our analysis can be considered "quasiclimatological", as the selected HPEs do not exhibit obvious biases with respect to the rain climatology in the region: (i) their seasonality follows the seasonal pattern of EM rainy days (Fig. 3), although HPEs occur more frequently at the beginning of the winter, presumably due to the high sea surface temperatures; (ii) HPEs are identified throughout the radar archive (with zero to seven HPEs per year); (iii) the frequency of the prevailing synoptic circulation patterns during HPEs (Table S1) resembles the frequency observed on rainy days (Marra et al., 2019); and (iv) HPEs characterised by ARST prevalence are common only during the transition seasons (Fig. 3 in this paper; e.g. De Vries et al., 2013).

For most examined durations, rain amounts defining the HPEs are larger near the Mediterranean coast, extending a few kilometres off- and onshore (Fig. 2). This resembles the observed pattern of high rain intensities near the coast, rather than inland (Karklinsky and Morin, 2006; Peleg and Morin, 2012; Sharon and Kutiel, 1986), which has also been reported for extreme precipitation quantiles observed from both weather radar and satellite sensors (Marra et al., 2017). 
In contrast, short durations (less than $12 \mathrm{~h}$ ) exhibit the highest rain intensities in the arid areas of the region. The frequency of rain in the arid areas is lower than in the rest of the region (Goldreich, 2012); thus, the $99.5 \%$ quantiles are based on fewer data. Nevertheless, the reported higher extreme rain amounts for shorter durations are in agreement with previous studies, which showed that highly localised convective rainfall is more common during HPEs in the desert than in other climatic environments in the EM (Marra et al., 2017; Marra and Morin, 2015; Sharon, 1972). In the mountains, the opposite case is seen: rainfall is produced more significantly through stratiform (or shallow convection) processes, and rain amounts for short durations are therefore relatively lower (Sharon and Kutiel, 1986). For the longer durations, rain intensities in the mountains are comparable to the intensities near the coast, probably resulting from the tendency of rain to persist in orography-affected regions (e.g. Panziera et al., 2015; Tarolli et al., 2012).

Affected by higher rain intensities, the centre of mass of the precipitation field for each of the HPEs is located near the EM coastline (Fig. 4). Nevertheless, a seasonal pattern appears, with a general landward shift of the centre of mass during the rainy season (Fig. 4). This is caused by land-sea differential heating and heat capacities and resembles the seasonal pattern of rain intensities in the EM (Goldreich, 1994; Sharon and Kutiel, 1986). In fact, this points out the observed preference of convective clouds to form above hightemperature surfaces, i.e. the sea surface or nearby coastal plains in autumn or early winter as well as farther inland in the spring. In terms of seasonality, the WRF-simulated centres of mass exhibit a similar, even if slightly less obvious, landward pattern. It must be noted that ARST-type events in the WRF results are biased eastwards compared with the radar results, which could be related to the WRF's worse performance with respect to such events (e.g. Sect. 4.3). Moreover, the exact location of the radar-observed centre of mass can suffer from range degradation, which may cause these centres to be biased towards the radar location.

According to the definition applied in this study, a given event can be considered a HPE for more than one duration. This can happen when the thresholds associated with the examined durations (Sect. 3.3) are exceeded either at the same location or in different regions. The durations associated with each HPE are listed in Table S1. The co-occurrence of each HPE duration with the rest of the examined durations is shown in Fig. 5; these co-occurrence values are similar to values determined in the Alps by Panziera et al. (2018). For example, $79 \%$ of the HPEs at a $24 \mathrm{~h}$ duration are also HPEs at a $72 \mathrm{~h}$ duration. Figure 5 indicates a high dependence (i.e. co-occurrence) of the short-duration HPEs (3-12 h). Similarly, there is a high dependence within the long-duration HPEs (24-72 h). Nevertheless, even the shortest (duration) HPEs examined here show a rather high co-occurrence with the longest (duration) HPEs (probabilities in all cases greater than or equal to 0.5 ).

\subsection{Bias}

Figure 6 shows the rainfall accumulated during all HPEs as estimated by the weather radar, modelled by the WRF, and measured by rain gauges (Fig. 6a, b, and d, respectively). Bias, defined herein as the normalised difference between WRF rainfall and radar QPE ( $\left.\frac{\mathrm{WRF}-\text { radar }}{\text { radar }}\right)$, in percent, is shown in Fig. 6c. In $69 \%$ of the studied region, the bias lies between $+200 \%$ and $-67 \%$, although some areas show a strong positive bias (Fig. 6c). The three stations highlighted in the figure (the values shown for radar and WRF represent the average of the nine pixels surrounding the gauge locations) show how this large bias is mostly caused by radar underestimation. In fact, these areas are generally located far from the radar or in the eastern portion of the radar coverage, where radar QPE suffers from range degradation and beam overshoot due to the presence of mountains. In some other areas, the bias seems related to residual beam blockages. Underestimation (a bias less than zero) is also apparent in regions with ground clutter, and some spatial inconsistencies related to the interpolation of a few fully blocked beams can also be noticed. To avoid interference of these radar estimation inaccuracies with our results, we focus only on the areas in which the bias lies between $+200 \%$ and $-67 \%$ (Fig. 6c). Still, a portion of the area close to the radar is characterised by negative bias, which could be attributed to simulated rain intensities that are too low. A similar pattern was also shown in Rostkier-Edelstein et al. (2014) where it was attributed to intensities that were too low during deep MCs.

\subsection{Visual, neighbourhood and object-based evaluation of WRF model simulations}

Visual comparison of observed (radar) and simulated (WRF) rainfall fields yielded mostly (subjectively) good results in terms of the spatial rainfall patterns, such as widespread versus localised rainfall. As an example, Fig. 7 presents a wellsimulated HPE case (HPE 1, Table S1). In addition, the distributions of rainfall among pixels were generally well represented (Fig. 7d). At the same time, pixel-based comparisons were deemed inappropriate for such an analysis, as shown in the scatter plot (Fig. 7e). Most of the examined HPEs led to similar observations, with the exception of two HPEs in which the WRF model clearly failed to represent the rainfall patterns. An example of such a poor simulation is given in Fig. 8 (HPE 5, Table S1). Both of these poorly simulated HPEs were characterised by relatively short total storm spans (1.7 and $2 \mathrm{~d})$, just exceeding the durations that defined them as HPEs (6 and 3-24 h, respectively). Synoptically, they were classified as ARSTs, a system generally characterised by local, short-lived convection associated with a localised rainfall-triggering mechanism (Armon et al., 2018). The skill of mesoscale models (e.g. WRF) is poorer in simulating these types of events, mainly due to their short predictability and stochastic nature (see e.g. Yano et al., 2018). Although a 
(a)

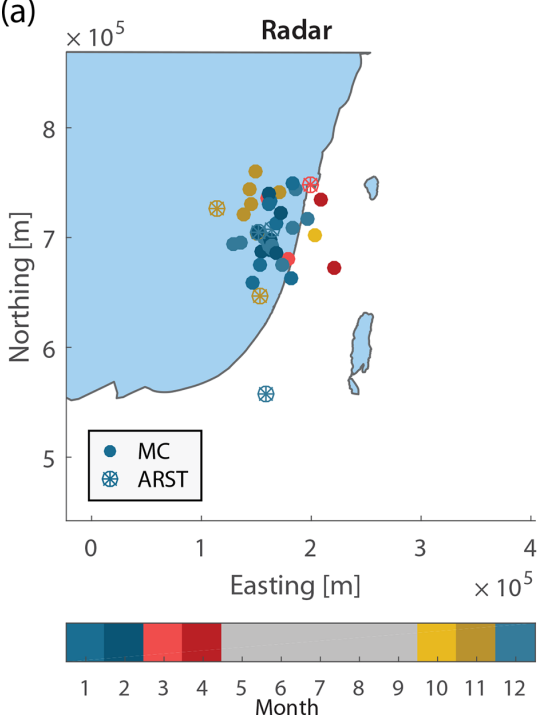

(b)

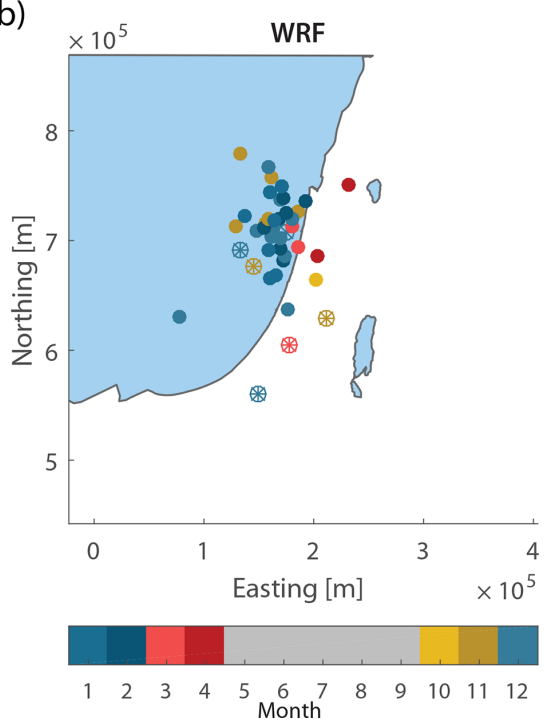

Figure 4. Centres of mass of cumulative rainfall of each of the HPEs derived from (a) the radar QPE and (b) WRF. Colours represent the month of occurrence. Synoptic classification according to Sect. 3.4.

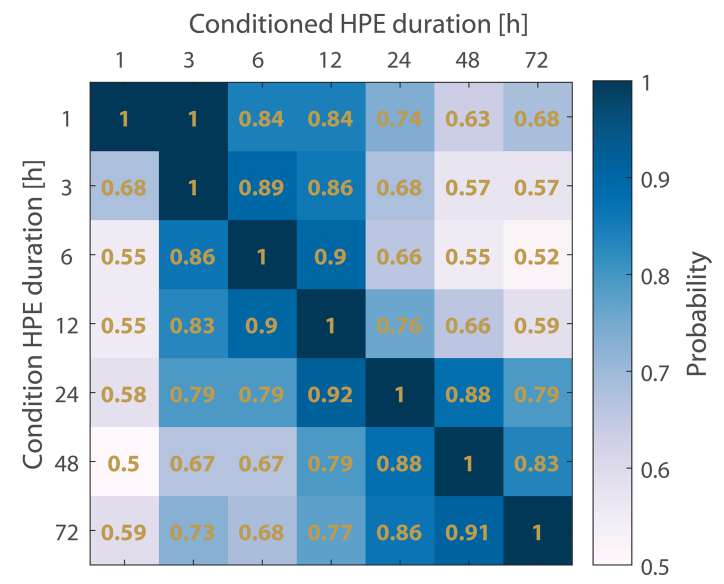

Figure 5. Probability of a HPE with a given examined duration listed on the $x$ axis conditioned on being a HPE with a duration listed on the $y$ axis.

deeper understanding of these aspects can be beneficial for improving future simulations, it falls outside the scope of this study and requires future dedicated research efforts.

The FSS of the first HPE (Fig. 7f) further manifests the accuracy of the simulated rainfall fields. The forecast has a larger FSS than the uniform FSS for all of the examined cumulative rainfall amounts less than or equal to $50 \mathrm{~mm}$, even at the model resolution $(1 \mathrm{~km})$. For larger cumulative rainfall, the FSS is unstable due to the limited number of observations of such cases; thus, no conclusions about the suitability of the results can be made for the occurrence of such high cumulative rainfall. It is only for the higher rainfall amounts, e.g. $125 \mathrm{~mm}$, corresponding to less than $1 \%$ of the pixels in this
HPE, that the model forecast is unskilled at all spatial scales, i.e. the uniform FSS outperforms the WRF forecast FSS (yet, these results are also based on a limited number of data).

During EM rainstorms, cumulative rainfall values are distributed unevenly in space, and extremely high rainfall depths are embedded within the larger aerial coverage of lower rainfall depths (e.g. Armon et al., 2018; Dayan and Morin, 2006; Morin et al., 2007). Thus, forecasting the spatial distribution (location and spatial frequency) of low cumulative rainfall is easier than forecasting the distribution of the high end of cumulative rainfall, even when averaging is conducted over large scales. The minimal scale (Roberts and Lean, 2008) at which the FSS of the model's forecast is higher than the uniform FSS was calculated for the occurrence of a range (1$200 \mathrm{~mm}$ ) of cumulative rainfall depths for all of the identified HPEs (Fig. 9). This allows for the estimation of the minimal scales for skilful rainfall detection for rain depths that are equal to or greater than an arbitrary cumulative rain depth threshold. For example, the original model resolution yielded a skilful forecast for the occurrence of cumulative rainfall depths of less than $25 \mathrm{~mm}$ in $50 \%$ of the HPEs (Fig. 9). The figure also shows that the occurrence of cumulative rainfall exceeding $45 \mathrm{~mm}$, in most cases, is only skilfully forecasted on a relatively large spatial scale (tens of kilometres). During ARSTs, the minimal scale was much higher than during MCs (not shown); however, it is important to remember that two of these HPEs were poorly simulated.

The SAL analysis (Fig. 10) showed good performance of the model, except for a substantial positive amplitude bias (inter-event amplitude component median of 0.80 , i.e. a bias of $130 \%$, as defined in Sect. 4.2, and interquartile range of 0.37-1.02). Two events stood out with a bias smaller than zero; these were the above-mentioned poorly simulated 

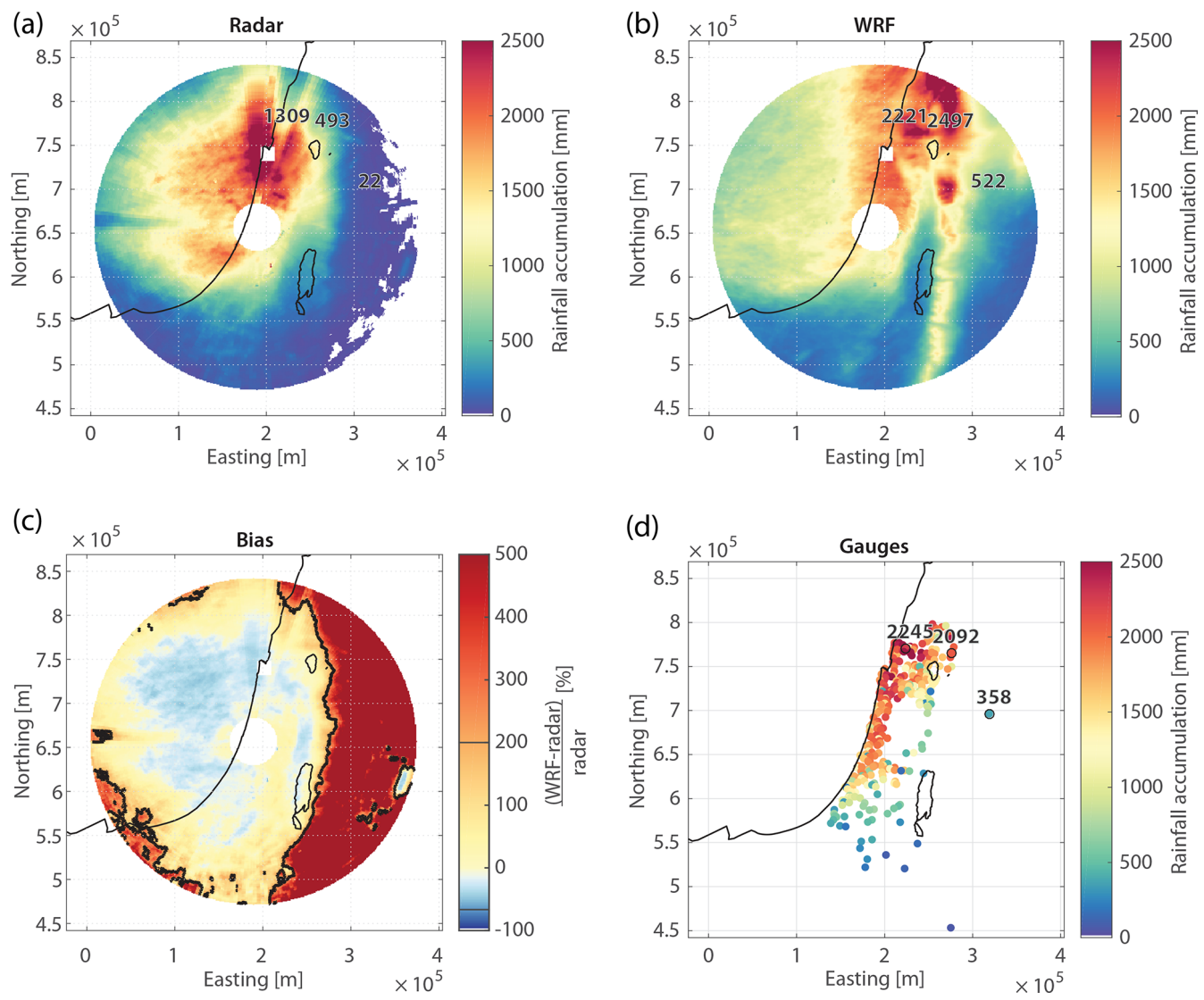

Figure 6. Total cumulative rainfall for all 41 HPEs from (a) radar-derived QPE, (b) WRF-derived rainfall, and (d) daily rain gauges. (c) WRF-to-radar rainfall accumulation bias (normalised difference; Sect. 4.2). The $200 \%$ and $-67 \%$ bias region is marked in black. Total accumulations ( $\mathrm{mm}$ ) measured at three rain gauges from regions where radar QPE is considered to be inferior are highlighted in panel (d); corresponding radar and WRF nine-pixel averaged values $(\mathrm{mm})$ centred over the same locations are shown in panels (a) and (b), respectively.

HPEs. In general, MC-type HPEs exhibited much greater bias than ARSTs (inter-event amplitude component median of 0.85 versus -0.07 ). However, it must be noted that the median of ARST-type HPEs includes the two poor simulations and is therefore predicted to be more negative. Surprisingly, where visual comparisons seemed better, and the structure component was closer to zero, the amplitude component actually suffered from more positive biases; for example, the structure component of HPE 1 (Fig. 7, Table S1) is 0.04, while its amplitude component is 1.03 . Furthermore, the median amplitude of events characterised by a structure component larger than the median structure is $27 \%$ higher than the amplitude of events with a structure smaller than the median value.

The structure component was well modelled in most cases, showing the ability of the WRF to accurately generate precipitation objects $(0.06$ and -0.06 to +0.26 for the median and interquartile range, respectively; 0.05 and 0.09 are the medians for MC- and ARST-type events, respectively). This is particularly important in regions and for events where rainfall is generated via both convective and stratiform processes, or when intense rainfall is embedded within larger-scale lowintensity precipitation (Wernli et al., 2009). The slight positive tendency of the structure component could either indicate that the model creates rain fields that are too smooth (lower intensity rain and objects that are too large), that radar data are too noisy, or, most probably, a combination of both error sources.

Relatively low values of the location component $(0.25$ and 0.18 to 0.31 for the median and interquartile range, respectively; 0.26 and 0.22 are the medians for MC- and ARST-type events, respectively) demonstrate the model's high capability to spatially distribute precipitation objects. Medially, $34 \%$ of this component is composed of the error in the centre of mass location (namely $L_{1}$; i.e. a median error of $30 \mathrm{~km}$ in the location of the centre of mass), and the rest is from the average location of each precipitation object $\left(L_{2}\right)$. Namely, the model prediction of the centre of mass of the rain field is quite satisfying, but the prediction of individual precipitation objects is a bit poorer. The contribution from the $L_{2}$ component to the location component (Sect. S2 in the Supplement) indicates that modelled precipitation objects are not 
(a)

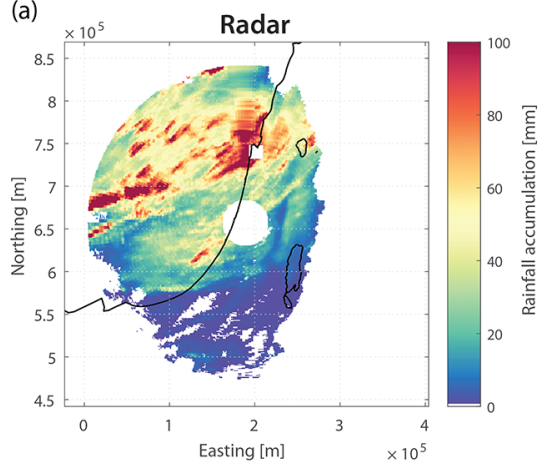

(d)

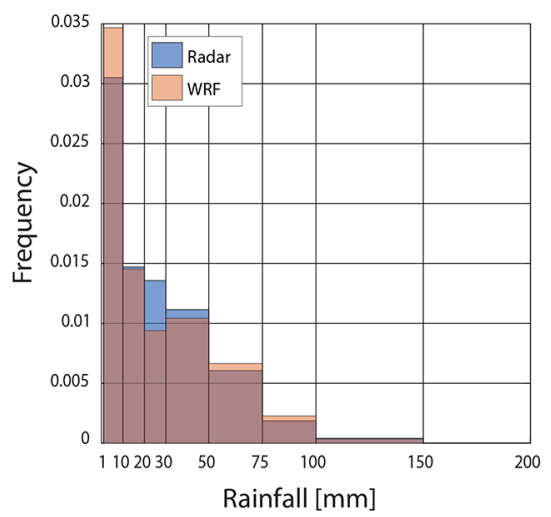

(b)

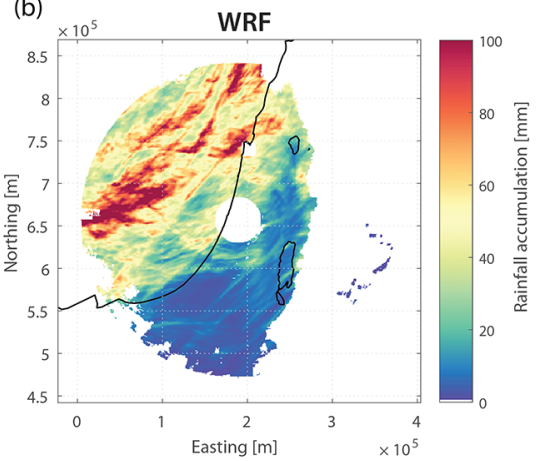

(e)

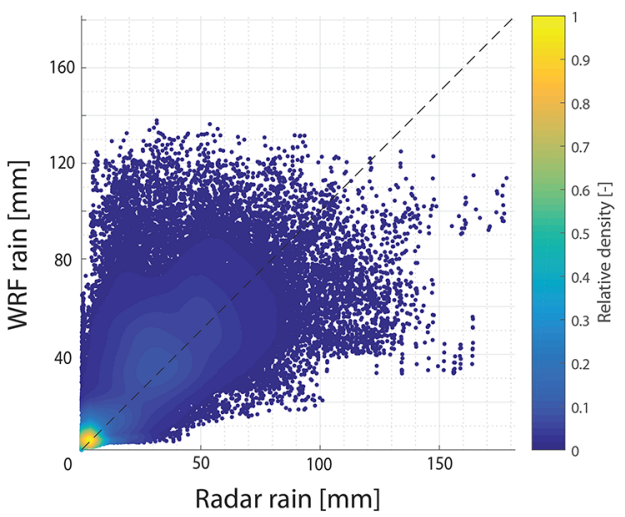

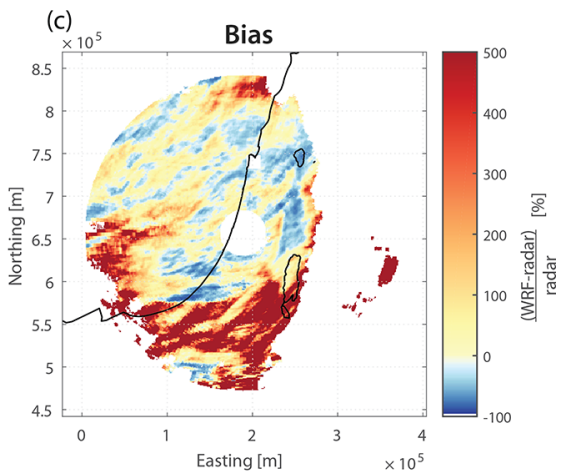

(f)

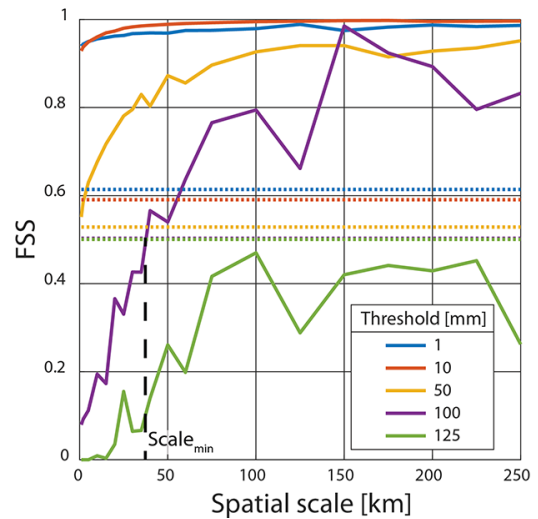

Figure 7. HPE 1 (09:00 LT, 2 November 1991 to 09:00 LT, 5 November 1991; all times in the figure are given in local winter time; see Table S1). Cumulative rainfall from (a) radar-derived QPE, (b) WRF-derived rainfall, and their ratio (c). A pixel-based comparison between rainfall accumulations using a histogram (d; zero rainfall is omitted) and scatter plot (e). Notice that although the rainfall distribution is quite well represented (d), results of a single pixel might deviate substantially from the $1: 1$ line (e; dashed). The fractions skill score (FSS) for the same event for various cumulative rainfall thresholds is presented in panel (f). Dashed lines are uniform FSSs for the same rainfall thresholds. The minimal scale for a valuable prediction for a $100 \mathrm{~mm}$ rain depth (at the crossing of the FSS and the uniform FSS; see Sect. S1 in the Supplement for details) is also shown (dashed black line).

(a)

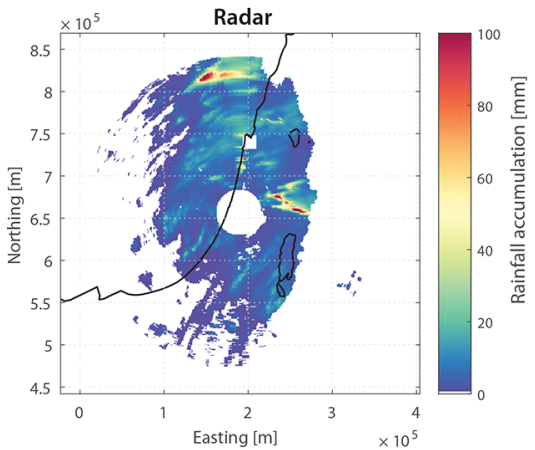

(b)

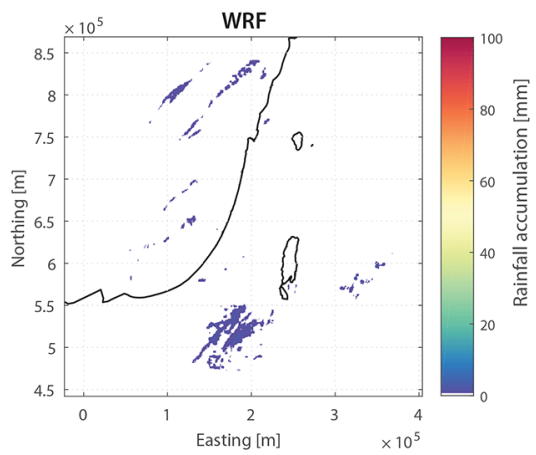

(c)

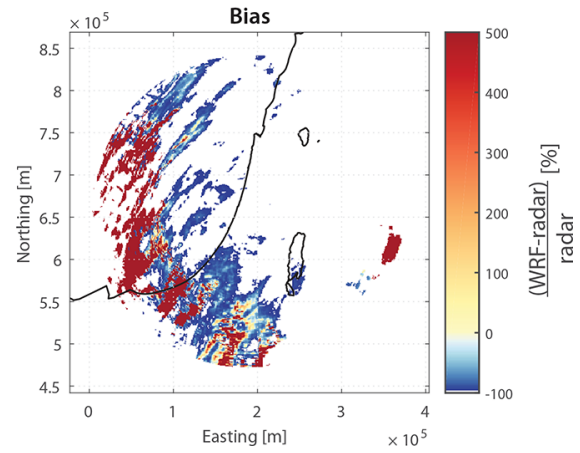

Figure 8. Same as Fig. 7a-c but for HPE 5 (09:00 LT, 31 March 1993 to 02:00 LT, 2 April 1993; Table S1).

distributed the same as the observed ones. This is probably due to a mismatch in the positioning of the simulated cells. Given the good ability of the radar to represent the location of rain cells, attenuation and range-degradation of the radar data should only have minor effects on $L_{2}$. In either case, location values are rather small, exhibiting good spatial distribution of precipitation objects. Nonetheless, the same two challenging ARST-type HPEs for which the model was unable to simulate the rainfall in a satisfying manner stand out with high 


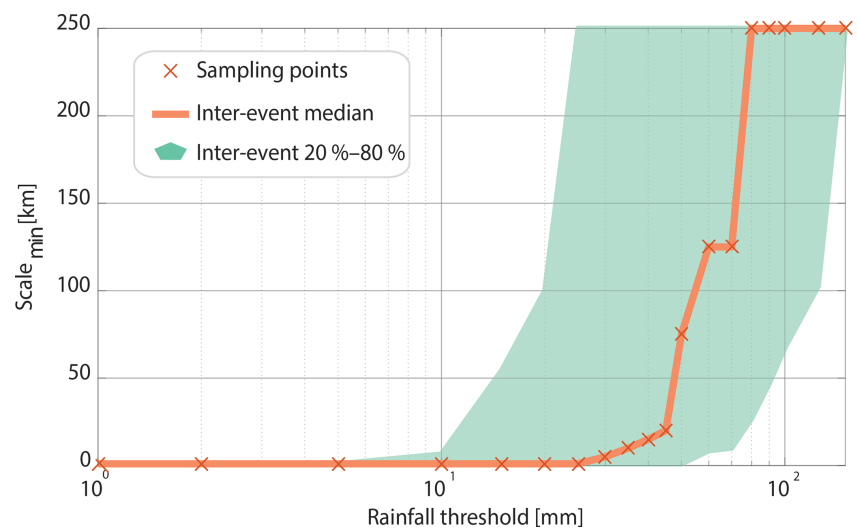

Figure 9. Minimal scale (see Fig. 7f and Sect. S1 in the Supplement) derived for all 41 events for various rainfall thresholds.

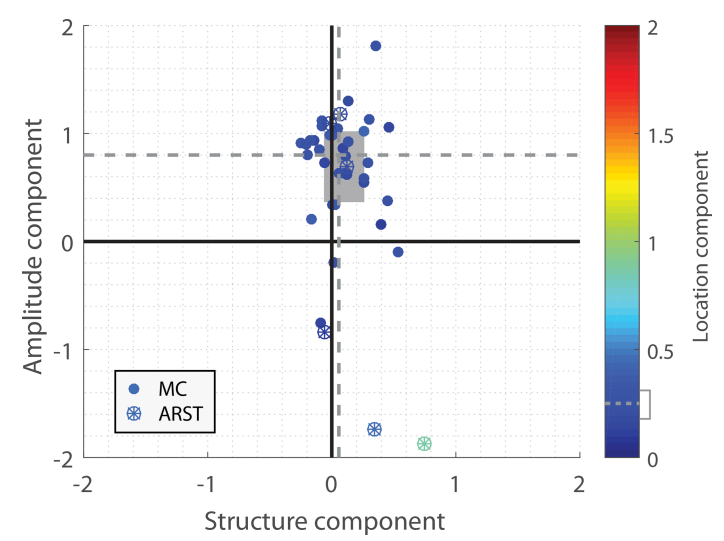

Figure 10. Structure-amplitude-location (SAL) analysis (Wernli et al., 2008). Each dot represents one event (classified according to Sect. 3.4). Dashed lines are median component values, and the grey rectangle represents the 25 th -75 th percentile range. The location component median value is 0.25 , and its 25 th-75th range is 0.18-0.31. More details are given in Sect. S2 in the Supplement.

location values (0.46 and 0.85$)$, yielding large spatial inconsistency with respect to observations (see above, e.g. Fig. 8).

The overall positive bias seen in the amplitude component (Fig. 10) could result from an underestimation of the radar QPE or an overestimation of the WRF simulation. Possible reasons leading to radar underestimation have been discussed above and may contribute to this bias even after the most severely biased regions have been masked. However, this positive bias still needs to be considered when addressing the actual cumulative rainfall amounts predicted by the model. In contrast with the overall bias (Sect. 4.2) almost no event showed a negative bias. Rostkier-Edelstein et al. (2014) mainly attributed positive biases to deep lows over complexterrain regions.

The overall good representation of precipitation objects implies that precipitation processes generated by the model represent actual processes and rainfall characteristics (Wernli et al., 2009).

\subsection{Characterisation of rainfall patterns}

\subsubsection{Areal rainfall}

Figure 11 shows the depth-area-duration (DAD) curves obtained from all $41 \mathrm{HPEs}$ for durations of $30 \mathrm{~min}, 6 \mathrm{~h}$, and $24 \mathrm{~h}$ from radar QPEs (Fig. 11a, c, and e, respectively) and WRF (Fig. 11b, d, and f, respectively). When referring to DAD analysis, the term "duration" represents the time period, over the course of each HPE, where maximum rainfall depths were observed. A major increase in cumulative rainfall with increased duration is observed for both the radar and WRF curves (Fig. 11g): for example, based on the radar, an area of $10^{3} \mathrm{~km}^{2}$ is medially covered by $9 \mathrm{~mm}$ for a duration of $0.5 \mathrm{~h}$, which increases to 35 and $60 \mathrm{~mm}$ for 6 and $24 \mathrm{~h}$, respectively (corresponding values from the WRF-derived rainfall are 4, 25 , and $50 \mathrm{~mm}$ ). This increase could be explained by either continuous rainfall or the frequent arrival of rain cells into the region. The latter increases the wet area and the cumulative rainfall in areas that have already experienced rainfall and is a major characteristic of HPEs in the EM (e.g. Armon et al., 2018, 2019; Sharon, 1972). Furthermore, over longer durations, this causes DAD curves for different events to be more similar to one another (e.g. Fig. 11e, f).

The inter-event spread and the difference in the DAD curves for MC and ARST (Fig. 11a-f) illustrate the various types of HPEs identified here. These types range between rainstorms exhibiting only a minimal increase in rainfall area with time, i.e. almost all of the rainfall precipitates during a short period; rainstorms composed of many rain cells passing through the same area; or long-lasting rainstorms. These results confirm previous findings by Armon et al. (2018) based on a more limited number of events: HPEs classified as ARSTs (Table S1) tend to have higher rain intensities for smaller regions and shorter periods than HPEs classified as MCs. MCs only exhibit higher rain intensities over larger regions and for longer durations.

It is important to note the difference between radar QPEand WRF-derived rainfall DAD curves. Higher rain values in the radar QPE over the range of smaller areas is the most obvious difference (Fig. 11g). Although these higher values may, at first glance, indicate that the WRF is unable to reproduce the high-intensity rainfall of the HPEs in the EM, it should be remembered that high-intensity radar QPEs can be of lower accuracy due to contamination from residual ground clutter or hail for short durations. This may affect the QPEs of the smaller areas more selectively. For instance, for one of the HPEs, an area of more than $100 \mathrm{~km}^{2}$ received a rain amount of greater than or equal to $100 \mathrm{~mm}$ in $0.5 \mathrm{~h}$ (Fig. 11a) - a value that exceeds the 200-year return period for the area (Morin et al., 2009). Other notable differences are some ARST-classified HPEs with WRF-derived DAD curves 
(a)

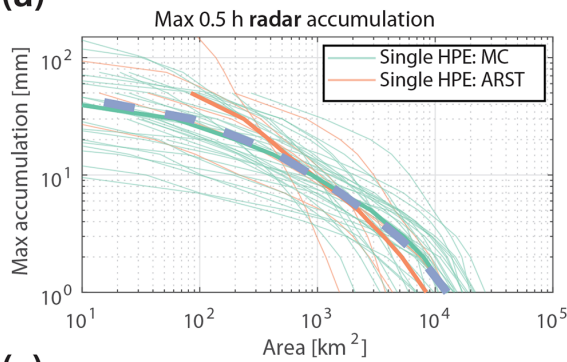

(c)

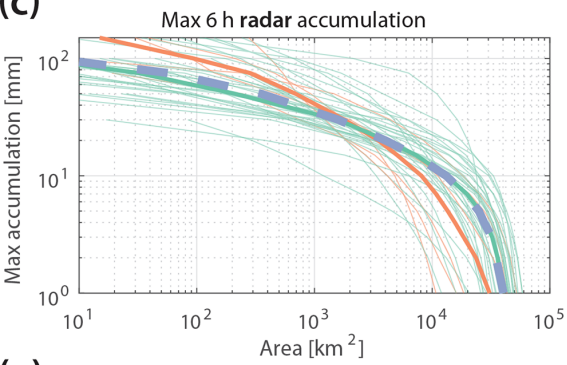

(e)

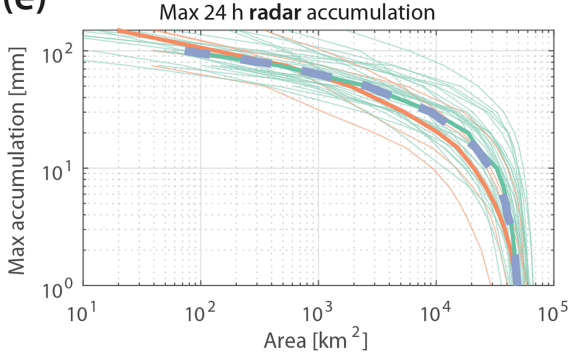

(b)

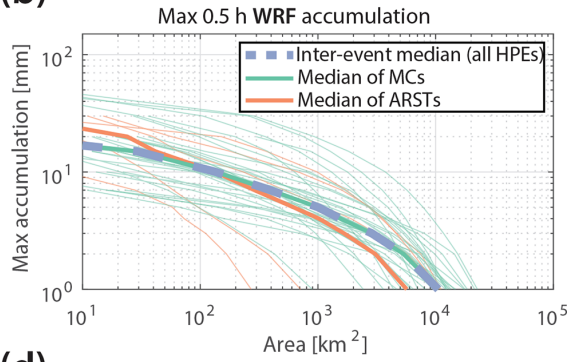

(d)

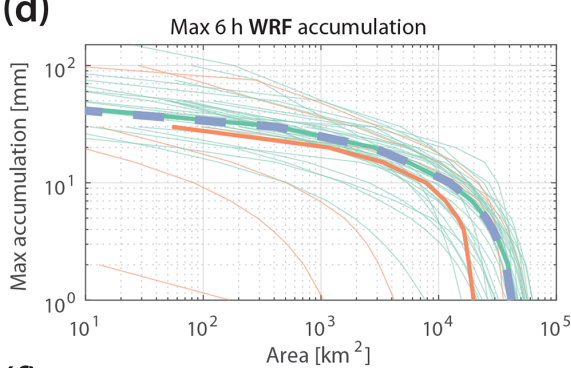

(f)
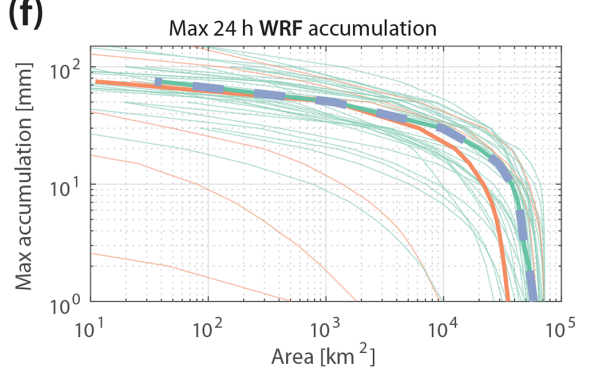

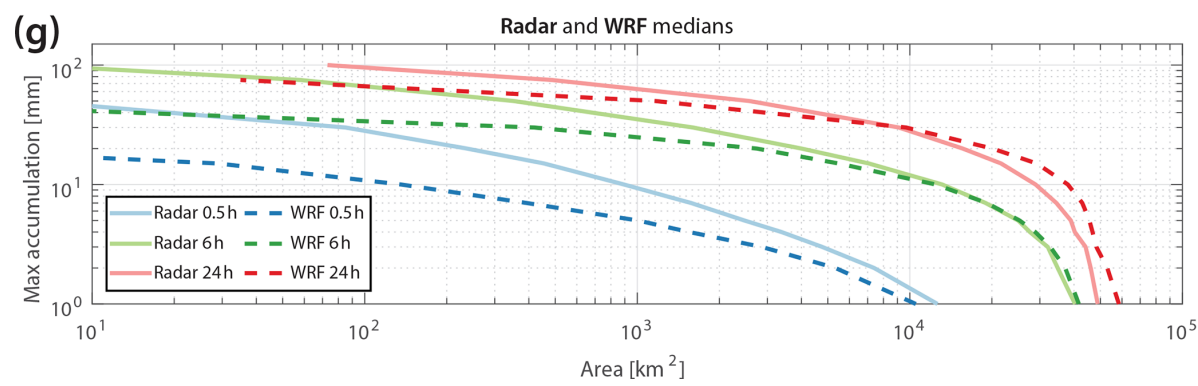

Figure 11. Depth-area-duration (DAD) curves showing the maximal amount of rainfall as a function of area, derived from the radar QPE (a, c, e) and from the WRF model (b, d, f) for $0.5 \mathrm{~h}(\mathbf{a}, \mathbf{b}), 6 \mathrm{~h}(\mathbf{c}, \mathbf{d})$, and $24 \mathrm{~h}(\mathbf{e}, \mathbf{f})$. Green and orange lines represent HPEs classified as MCs and ARSTs, respectively. Thick lines represent the inter-event median. This median is compared between radar-QPE and WRF rainfall in panel $(\mathbf{g})$.

(Fig. 11b, d, f) consisting of the two WRF-unresolved HPEs mentioned above, and yielding a median ARST curve that is much lower than the radar-derived curve.

The reported differences between WRF- and radar-derived curves result in an overall greater area-over-threshold radar curves for the high-rainfall thresholds, especially for the short durations. For long durations and low rainfall thresholds, the WRF area is larger (Fig. 11), reflecting the positive bias mentioned above.

\subsubsection{Autocorrelation structure of convective rainfall}

HPEs in the EM are commonly composed of highly localised convective rain cells. This is well reflected in the sharp decrease of the 1-D autocorrelation describing the convective rain fields (Fig. 12a, b) obtained using all of the convective rain fields throughout the 41 HPEs $(n=11731$ snapshots for radar and $n=14323$ for WRF). The median decorrelation distance (defined as the distance in which the correlation drops to $r=e^{-1}$, i.e. parameter $b$ of the 1-D exponential fit, Eq. 1) of all convective rain snapshots from the radar data is $9 \mathrm{~km}$ (7 km using the WRF-derived rainfall) and ranges 

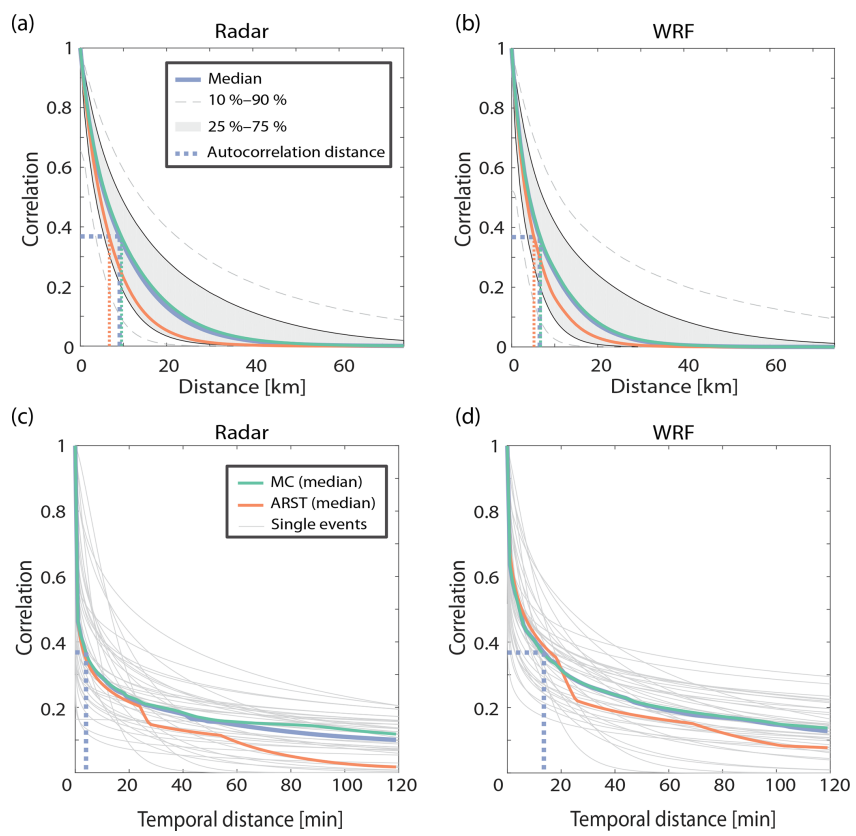

Figure 12. A 1-D exponential fitting of the rain field spatial $(\mathbf{a}, \mathbf{b})$ and temporal (c, d) autocorrelation values from radar-derived QPE $(\mathbf{a}, \mathbf{c})$ and from the WRF model $(\mathbf{b}, \mathbf{d})$. These were computed using 10 min snapshots of rain and only for periods where convective rainfall is present. Quantiles in spatial autocorrelation $(\mathbf{a}, \mathbf{b})$ represent 11731 snapshots of radar $10 \mathrm{~min}$ data (10095 of which come from MC-type events) and 14323 WRF rainfall snapshots (12 220 of which come from MC-type events). Temporal autocorrelation plots (c, d) are composed of the 41 examined HPEs (grey) as well as their median values for all events (purple), for MC-type only (green) and for ARST-type only (orange).

between 3 and $23 \mathrm{~km}$ (for the $10 \%$ and $90 \%$ quantiles, respectively; 2 and $20 \mathrm{~km}$ using WRF). The median decorrelation distance during ARSTs is shorter than during MCs, as obtained from both the radar (7 and $10 \mathrm{~km}$, respectively for ARSTs and MCs) and the WRF (5 and $7 \mathrm{~km}$, respectively). These values are comparable to previously reported observations (e.g. Ciach and Krajewski, 2006; Morin et al., 2003; Peleg and Morin, 2012; Villarini et al., 2008) and are somewhat larger than the reported values for the south-eastern part of the area by Marra and Morin (2018). However, it should be noted that Marra and Morin (2018) examined 1 min rainfall fields versus the 10 min fields examined here.

The median of the temporal decorrelation distance (Fig. 12c, d) was roughly 4 min (approximately $14 \mathrm{~min}$ for the WRF), and it ranged between less than 1 and $19 \mathrm{~min}$ (10\% and $90 \%$ quantiles, respectively; 3 and 29 min using WRF). Despite agreeing with the results of Marra and Morin (2018), the exact temporal decorrelation distance is somewhat dubious, as it is shorter than the time step used for its calculation (10 min). For this reason, we do not report the small differences that exist between the two synoptic systems. The larger temporal correlation in the WRF-derived rainfall is expected, because radar QPE suffers from temporal inconsistencies (e.g. when a convective cell passes through a region with beam blockages). Nevertheless, such a short temporal decorrelation confirms the local and spotty nature of rainfall characterising HPEs in the region.

The declining pattern of the 1-D autocorrelation overlooks the 2-D spatial heterogeneity of the autocorrelation field. The ellipticity of the 2-D autocorrelation yielded a median across all convective rain fields value of 0.56 ( 0.62 and 0.54 in ARST- and MC-type events, respectively), with a range of $0.33-0.80$ (10\%-90\% quantiles). WRF-derived ellipticity values were almost the same: 0.58 (0.68 and 0.68 in ARSTand MC-type events, respectively), with a range of 0.33 0.79 . These autocorrelation ellipses in the radar data were oriented $13^{\circ}$ anticlockwise from the east-west axis (median value; 7 and $14^{\circ}$ for ARST- and MC-types, respectively) and $22^{\circ}$ for the WRF ellipses (10 and $24^{\circ}$ for ARST- and MCtypes, respectively). These values are similar to the orientation of radar rain cells in the eastern part of the region (Belachsen et al., 2017), but they are somewhat different from the orientation of autocorrelation fields from the southeastern part of the region (Marra and Morin, 2018). Orientations found in the present analysis cover the entire evolution of HPEs and, thus, include both south-west (mainly at the beginning of the storm) and north-west (mainly at the end of the storm) alignments of rain cells. Therefore, they are oriented more anticlockwise than the autocorrelation fields from the south-eastern part of the region (Marra and Morin, 2018), which commonly represents rainfall at the end of a rainstorm (Armon et al., 2019). Moreover, Marra and Morin (2018) examined 1 min snapshots, whereas here advection can play a role in the examined $10 \mathrm{~min}$ time interval. Finally, Marra and Morin (2018) only analysed 11 events; thus, interevent variance may still play a large role in their results. The high agreement between modelled and observed rain field ellipticity and orientation also demonstrates the high skill of the WRF simulations in accurately representing convection in the region and, thus, reproducing rain cell properties.

\subsection{Summary of results}

This work characterises rainfall patterns during 41 HPEs in the EM and evaluates the ability of a high-resolution WRF model to properly simulate their cumulative rain field and spatiotemporal behaviour, with a specific emphasis on their convective component and the prevailing synoptic system. A successful outcome will pave the way for downscaling global climate projections to induced changes in rainfall patterns on a regional scale during HPEs, with an understanding of the strengths and weaknesses of the regional results. However, it is important to note that the identification of HPEs in global climate models constitutes yet another challenge (see discussions e.g. in Chan et al., 2018; Gómez-Navarro et al., 2019; Meredith et al., 2018). 
To overcome the diverse climatology of the EM, we identified HPEs using pixel-based weather radar climatology. We used a uniquely long, quality-controlled and gaugeadjusted high-resolution weather radar archive to characterise the rainfall patterns. A convection-permitting highresolution WRF model configuration was used to simulate the same HPEs, and the results of this modelling effort were compared to the radar QPEs. For most of the 41 HPEs, model simulations gave valuable results: using the FSS we determined that (i) WRF simulations are highly accurate for cumulative rainfall less than $25 \mathrm{~mm}$ (Fig. 9; Sect. 4.3), and (ii) accumulation of more than $45 \mathrm{~mm}$ produces variable results among different cases (Figs. 7, 8, and 9; Sect. 4.3). In other words, skilful results are gained if the model output is averaged over at least a few tens of kilometres. SAL analysis of cumulative rainfall showed that the rainfall location and structure were correctly reproduced by the model and were similar to the weather radar data observations in 39 out of the 41 HPEs. Conversely, rainfall amplitude was highly (positively) biased, with some of the bias likely due to radar underestimation; however, a model positive bias cannot be excluded. Furthermore, we found that ARST-type HPEs are not as well simulated as MC-type events, at least in terms of the FSS and the spatial structure of rainfall.

In general, rain amounts forming HPEs are higher near the EM coastline with the exception of (i) short (examined) durations, for which the highest rain amounts are observed in the desert regions, and (ii) the longer-duration HPEs, for which rain amounts in mountainous regions are comparable to those on the coast. Identified HPEs occurred during the wet season (October-April), primarily in NovemberFebruary. Their centre of mass was close to the Mediterranean coastline and shifted landward during the season. We analysed the areal distribution of rainfall for various durations, the autocorrelation structure of the convective rainfall fields, and DAD curves to obtain quantitative information on the characteristics of the rainfall fields, the ability of the WRF model to simulate them, and the processes generating them, such as the aggregation of small and short-lived rain cells to produce a HPE.

\section{Discussion}

\subsection{Spatial distribution of rain-intensity thresholds defining HPEs}

High-intensity threshold-forming HPEs near the Mediterranean Sea (Fig. 2) are expected, due to its warm surface waters and high moisture fluxes; they are also apparent in other regions of the Mediterranean (e.g. Dayan et al., 2015; Ivatek-Šahdan et al., 2018; Khodayar et al., 2018; Pastor et al., 2002; Peleg et al., 2018; Tarolli et al., 2012). High rain intensities in the desert are somewhat more intriguing. For example, Warner (2004) mentioned that there is con- trasting evidence with respect to whether rain intensities in the desert are higher than in non-desert regions. An opposing trend between mean annual rainfall and short-duration rain intensities was also described by Sharon and Kutiel (1986), using rain gauges, and by Marra and Morin (2015), using both rain gauges and weather radar. This trend is related to the higher surface temperatures in desert regions, which may enhance convective activity (e.g. Peleg et al., 2018), as well as to a deeper boundary layer (e.g. Gamo, 1996; Marsham et al., 2013) and the prevalence of rainfall from ARST circulation patterns, which generally cause higher rain intensities (Armon et al., 2018; Nicholson, 2011; Sharon and Kutiel, 1986; De Vries et al., 2013). Such a sharp spatial change in the climatology of the rain intensities defining HPEs can only be captured using high-resolution, high-spatiotemporalcoverage data (such as the radar QPE presented here) and reproduced by high-resolution, convection-permitting models.

\subsection{Multiple-duration HPEs and their relation to flash floods}

Mediterranean-climate, and even more so desert-climate HPEs, can produce rain amounts of the same order of magnitude as the mean annual rainfall (e.g. Nicholson, 2011; Schick, 1988; Tarolli et al., 2012). Thus, the frequent cooccurrence of short- and long-duration HPEs is to be expected, and dividing events into short versus long duration is not straightforward. However, our dataset comprises events with different characteristics: local and intense as well as widespread; the rainfall-triggering mechanisms and potential hydrological impact can be quite different.

Comparison of the DAD curves in Fig. 11 with reported floods in Mediterranean and desert environments in the EM (Zoccatelli et al., 2019) shows that a portion of the HPEs analysed here are prone to produce floods in smaller catchments and in desert regions, characterised by rather short (approximately $7 \mathrm{~h}$ ) and low total precipitation rain spells. Other HPEs analysed here could generate floods in larger catchments and in Mediterranean climate regions, characterised by longer rain spells and higher rain depths $(1 \mathrm{~d}$ and $52 \mathrm{~mm}$, respectively) (Zoccatelli et al., 2019). Specifically, the convective part of the rainstorm is known to generate the highestmagnitude floods, even in Mediterranean climate areas (e.g. Rinat et al., 2018; Tarolli et al., 2012). The short spatiotemporal autocorrelation distances observed for the convective rain fields once again highlight the spottiness of HPE rainfall in the EM region (Sharon, 1972), and they were well simulated by the WRF model (Fig. 12).

\subsection{Identification and characterisation of HPEs using weather radar and a high-resolution weather model}

ARST synoptic circulation is often associated with flash floods in the desert part of the region (Ashbel, 1938; Kahana 
et al., 2002; Krichak et al., 1997), and its rainfall is commonly caused by the mesoscale triggering of convection (Armon et al., 2018); therefore, it is less predictable (e.g. Keil et al., 2014), as is also evident from this study (e.g., Figs. 10, 11). ARSTs are also characterised by smaller rain field autocorrelation distance (Fig. 12). Thus, it is crucial for future studies to understand the reasons for the poor modelling results observed for 2 of these 41 HPEs. This is evident in the coarser model domains as well (Fig. S2). Possible aspects to be inspected include the parameterisation schemes adopted (Table 1); however, as we used convection-permitting resolution, problems could arise from other issues. In particular, as errors in the moisture field tend to propagate rapidly, the correct amount of moisture must be entered into the model in the correct location to properly reproduce rainfall on the mesoscale (e.g. Rostkier-Edelstein et al., 2014; Zhang et al., 2007). In this study, we used ERA-Interim reanalysis data (approximately an $80 \mathrm{~km}$ horizontal resolution), which may not be accurate enough to resolve some conditions, but they are on the same scale as outputs of global climate models. Future studies should consider using higher-resolution input data, such as the newly released ERA5 data (Hersbach, 2016).

Nonetheless, the autocorrelation structure of the rain fields was in generally well simulated for most HPEs (Sect. 4.4.2). This suggests that even if an event is less predictable, some of the rainfall characteristics can still be simulated. This result is encouraging in terms of the use of convection-permitting models, e.g. in nowcasting, because it means that wind patterns (determining orientation and ellipticity) are well forecasted.

The use of a long record of radar QPEs enabled us to provide a high-resolution quasi-climatological characterisation of the rainfall patterns during HPEs with a resolution and spatial coverage that cannot be achieved using rain gauges. However, rainfall characteristics could not be adequately retrieved in regions suffering from radar data-acquisition problems. Nevertheless, the resultant skill of the WRF rainfall fields supports its use for representing HPEs in regions that are not well covered by radars. As the analyses were performed in a region exhibiting a strong climatic gradient, we suggest that similar results be obtained in other parts of the world, at least in areas characterised by similar climates.

The main added value of convection-permitting models is seen in area averages, rather than over small-scale regions (Roberts, 2008). Therefore, over large catchments (e.g. larger than a few hundred square kilometres, as suggested by the minimal scale presented in Fig. 9), their forecasts are expected to be relatively useful and accurate. Nonetheless, the use of a deterministic convection-permitting model is still unsatisfactory for pinpointing the highest observed rain accumulations. Although such models are becoming more common in weather and climate forecasting and research (Prein et al., 2015), they are still not adequate for short-term hydrological applications, such as flash flood predictions. The structure of the high cumulative rainfall is predicted quite well; however, it still suffers from a positive bias, and is not exactly well located (e.g. Figs. 9, 10). In order to provide better flood predictions, especially for small catchments and for flash flood generation controlled by infiltration-excess, there is a need for more structured approaches, such as ensemble forecasts and data assimilation of meteorological observations (e.g. Diomede et al., 2014; Gustafsson et al., 2018; Hamill et al., 2008; Rostkier-Edelstein et al., 2014). These would provide probabilistic (rather than deterministic) information, and could therefore account for the uncertainty characterising the location in high-resolution models (e.g. Alfieri et al., 2012; Vincendon et al., 2011).

Characterisation of rainfall patterns during HPEs has special significance in the EM: on the one hand, the region suffers from a severe water shortage; on the other hand, it is prone to devastating floods. Both are predicted to worsen in response to climate change (e.g. Alpert et al., 2002; Kelley et al., 2015; Sowers et al., 2010). Modelling could help understand the effects of climate change on these two aspects but, before assessing the projections for a change in rainfall patterns induced by climate change, we need to consider what aspects of these patterns are still not well captured by weather models, posing a challenge for future predictions. For example, we showed here that rainfall during ARSTs is less adequately forecasted. These ARST HPEs are known to cause flash floods and, as ARSTs might occur more frequently due to global warming (Hochman et al., 2018a), this low predictability should be addressed.

The work presented herein is a step towards better understanding rainfall patterns during HPEs in the EM; we are currently extending the research to relate specific rainfall patterns to atmospheric conditions at high-resolution and to analyse how the predicted climate change will affect the rainfall characteristics outlined in this paper. Another research direction worth following would involve combining our procedures with satellite-based climatology. However, to date, satellite products present temporal $(\geq 0.5 \mathrm{~h}$, mostly $\geq 3 \mathrm{~h}$ ) and spatial $\left(\geq 0.04^{\circ}\right.$, mostly $\left.\geq 0.25^{\circ}\right)$ resolutions (e.g. Ashouri et al., 2015; Gehne et al., 2016) that are insufficient to adequately sample the fine-scale properties of convective rainfall fields, particularly in arid areas.

\section{Conclusions}

This study presents the identification of HPEs using a weather radar. These HPEs were then simulated using a highresolution NWP model and evaluated, focusing on the spatiotemporal patterns of the rainfall fields. The main conclusions of this characterisation and evaluation are as follows:

- HPEs in the EM are common between October and April, and their occurrences are focused in the period between November and February. The HPEs' centre of 
mass is located near the Mediterranean coastline and moves landward during the rainy season.

- For most examined storm durations, the rain amounts forming HPEs (i.e. larger than $99.5 \%$ of all rainy hours) are higher near the Mediterranean coast. For short durations, the highest HPE rain amounts are located in the desert, and for long durations, mountainous and coastal regions exhibit similar values.

- HPEs consist of small convective rain cells (spatial and temporal decorrelation of roughly $9 \mathrm{~km}$ and $4 \mathrm{~min}$, respectively) that form a highly variable rainy area over short durations. The size of the rainy region increases with duration and becomes more homogeneous between events.

- A convection-permitting high-resolution WRF model can simulate most HPEs, apart from some of the shortest, most localised storms, associated mainly with ARSTs.

- Rainfall structure is well simulated. Nevertheless, it is slightly less variable than the observed structure, and is characterised by a significant positive bias in rain volume. This can be, at least partially, attributed to radar underestimations.

- The location of rainfall is generally predicted properly. About a third of the location error comes from a spatial shift of $30 \mathrm{~km}$ in the centre of mass, and the rest comes from the difference in the location of specific precipitation objects.

- The minimal scale for forecasting total rainfall depths of less than $25 \mathrm{~mm}$ is $1 \mathrm{~km}$. It raises to a few tens of kilometres in cumulative rainfall of more than or equal to $25 \mathrm{~mm}$, and even more for rain depths of more than $45 \mathrm{~mm}$. For such large cumulative rain depths the minimal scale becomes highly variable between events.

Use of a high-resolution weather model that can reproduce rainfall patterns during HPEs is of great importance in predicting the hydrometeorology of flood-producing rainstorms. However, these must be elaborated using, e.g. ensemble runs of the model. Convection-permitting models may also help assess changes in precipitation induced by climate change, although if they are composed of HPEs that are less skilfully predicted at present, they should be examined with caution.

Israel Meteorological Service: Rain gauge data, available at: https://ims.data.gov.il/, last accessed: May 2019.

Data availability. Rain gauge data were provided and preprocessed by the Israel Meteorological Service (https://ims.data.gov.il/, Israel Meteorological Service, 2019; they are freely available in Hebrew only). Rain gauge data from the Kingdom of Jordan were obtained using the Global Historical Climatology NetworkDaily (GHCN-Daily), Version 3, NOAA National Climatic Data Center (https://doi.org/10.7289/V5D21VHZ; Menne et al., 2012, last access: May 2019). Shacham radar data were provided by the EMS-Mekorot projects (http://www.emsmekorotprojects.com, EMS Mekorot Projects Ltd, 2019). Corrected and gauge-adjusted data (Marra and Morin, 2015) are available in the form of images upon request to the head of the Hydrometeorology lab at the Hebrew University of Jerusalem, Efrat Morin (efrat.morin@mail.huji.ac.il). ERA-Interim data were downloaded from the Research Data Archive at the National Center for Atmospheric Research, Computational and Information Systems Laboratory (European Centre for Medium-Range Weather Forecasts, 2012). The WRF namelist.input file can be found in the Supplement of this article.

Supplement. The supplement related to this article is available online at: https://doi.org/10.5194/hess-24-1227-2020-supplement.

Author contributions. MA and EM conceptualised this work. The methodology was developed by all authors. Data curation and formal analysis were performed by MA and FM. Funding was acquired by EM, YE, FM, and DRE. EM and YE supervised the work. MA wrote the original draft of this paper, which was reviewed and edited by all authors.

Competing interests. The authors declare that they have no conflict of interest.

Special issue statement. This article is part of the special issue "Hydrological cycle in the Mediterranean (ACP/AMT/GMD/HESS/NHESS/OS inter-journal SI)". It is not associated with a conference.

Acknowledgements. This study is a contribution to the PALEX "Paleohydrology and Extreme Floods from the Dead Sea ICDP Core" project and is a contribution to the HyMeX programme. The authors thank Pinhas Alpert for the updated synoptic classification data. The authors also thank the three anonymous reviewers and the editor, Marie-Claire ten Veldhuis, for their constructive comments, which helped to improve this paper.

Financial support. This research has been supported by the Deutsche Forschungsgemeinschaft (grant no. BR2208/13-1/-2), the Israel Science Foundation (grant no. 1069/18), the NSF-BSF (grant no. BSF 2016953), and the Israel Ministry of Science and Technology (grant no. 61792). It is also partially funded by the Advanced School for Environmental Studies at the Hebrew University of Jerusalem and the Israel Water Authority.

Review statement. This paper was edited by Marie-Claire ten Veldhuis and reviewed by three anonymous referees. 


\section{References}

Ahlborn, M., Armon, M., Ben Dor, Y., Neugebauer, I., Schwab, M. J., Tjallingii, R., Shoqeir, J. H., Morin, E., Enzel, Y., and Brauer, A.: Increased frequency of torrential rainstorms during a regional late Holocene eastern Mediterranean drought, Quaternary Res., 89, 425-431, https://doi.org/10.1017/qua.2018.9, 2018.

Alfieri, L., Thielen, J., and Pappenberger, F.: Ensemble hydrometeorological simulation for flash flood early detection in southern Switzerland, J. Hydrol., 424-425, 143-153, https://doi.org/10.1016/j.jhydrol.2011.12.038,, 2012.

Alpert, P. and Shay-EL, Y.: The moisture Source for the Winter Cyclones in the Eastern Mediterranean, Israel Meteorological Research Papers, 5, 20-27, 1994.

Alpert, P., Ben-Gai, T., Baharad, A., Benjamini, Y., Yekutieli, D., Colacino, M., Diodato, L., Ramis, C., Homar, V., Romero, R., Michaelides, S., and Manes, A.: The paradoxical increase of Mediterranean extreme daily rainfall in spite of decrease in total values, Geophys. Res. Lett., 29, 1536, https://doi.org/10.1029/2001GL013554, 2002.

Alpert, P., Osetinsky, I., Ziv, B., and Shafir, H.: Semi-objective classification for daily synoptic systems: Application to the eastern Mediterranean climate change, Int. J. Climatol., 24, 1001-1011, https://doi.org/10.1002/joc.1036, 2004.

Amponsah, W., Ayral, P.-A., Boudevillain, B., Bouvier, C., Braud, I., Brunet, P., Delrieu, G., Didon-Lescot, J.-F., Gaume, E., Lebouc, L., Marchi, L., Marra, F., Morin, E., Nord, G., Payrastre, O., Zoccatelli, D., and Borga, M.: Integrated highresolution dataset of high-intensity European and Mediterranean flash floods, Earth Syst. Sci. Data, 10, 1783-1794, https://doi.org/10.5194/essd-10-1783-2018, 2018.

Anthes, R. A., Kuo, Y.-H., Baumhefner, D. P., Errico, R. M., and Bettge, T. W.: Predictability of Mesoscale Atmospheric Motions, Adv. Geophys., 28, 159-202, https://doi.org/10.1016/S00652687(08)60188-0, 1985.

Armon, M., Dente, E., Smith, J. A., Enzel, Y., and Morin, E.: Synoptic-scale control over modern rainfall and flood patterns in the Levant drylands with implications for past climates, J. Hydrometeorol., 19, 1077-1096, https://doi.org/10.1175/JHMD-18-0013.1, 2018.

Armon, M., Morin, E., and Enzel, Y.: Overview of modern atmospheric patterns controlling rainfall and floods into the Dead Sea: Implications for the lake's sedimentology and paleohydrology, Quaternary Sci. Rev., 216, 58-73, https://doi.org/10.1016/j.quascirev.2019.06.005, 2019.

Ashbel, D.: Great floods in Sinai Peninsula, Palestine, Syria and the Syrian Desert, and the influence of the Red Sea on their formation, Q. J. Roy. Meteor. Soc., 64, 635-639, 1938.

Ashouri, H., Hsu, K. L., Sorooshian, S., Braithwaite, D. K., Knapp, K. R., Cecil, L. D., Nelson, B. R., and Prat, O. P.: PERSIANNCDR: Daily precipitation climate data record from multisatellite observations for hydrological and climate studies, B. Am. Meteorol. Soc., 96, 69-83, https://doi.org/10.1175/BAMS-D-1300068.1, 2015.

Ban, N., Schmidli, J., and Schär, C.: Evaluation of the convection-resolving regional climate modeling approach in decade-long simulations, J. Geophys. Res., 119, 7889-7907, https://doi.org/10.1002/2014JD021478, 2014.
Belachsen, I., Marra, F., Peleg, N., and Morin, E.: Convective rainfall in a dry climate: relations with synoptic systems and flashflood generation in the Dead Sea region, Hydrol. Earth Syst. Sci., 21, 5165-5180, https://doi.org/10.5194/hess-21-5165-2017, 2017.

Bližňák, V., Kašpar, M., and Müller, M.: Radar-based summer precipitation climatology of the Czech Republic, Int. J. Climatol., 38, 677-691, https://doi.org/10.1002/joc.5202, 2018.

Bloschl, G. and Sivapalan, M.: Scale Issues in Hydrological Modelling: a Review, Hydrol. Process., 9, 251-2901, 1995.

Bogaard, T. A. and Greco, R.: Landslide hydrology: from hydrology to pore pressure, WIRES-Water, 3, 439-459, https://doi.org/10.1002/wat2.1126, 2016.

Borga, M. and Morin, E.: Characteristics of Flash Flood Regimes in the Mediterranean Region, in: Storminess and Environmental Change Climate Forcing and Responses in the Mediterranean Region, edited by: Diodato, N. and Bellocchi, G., chap. 5, 65-76, Springer Netherlands, Dordrecht, https://doi.org/10.1007/97894-007-7948-8_5, 2014.

Borga, M., Boscolo, P., Zanon, F., and Sangati, M.: Hydrometeorological Analysis of the 29 August 2003 Flash Flood in the Eastern Italian Alps, J. Hydrometeorol., 8, 1049-1067, https://doi.org/10.1175/JHM593.1, 2007.

Borga, M., Anagnostou, E. N., Blöschl, G., and Creutin, J. D.: Flash flood forecasting, warning and risk management: The HYDRATE project, Environmental Science and Policy, 14, 834844, https://doi.org/10.1016/j.envsci.2011.05.017, 2011.

Borga, M., Stoffel, M., Marchi, L., Marra, F., and Jakob, M.: Hydrogeomorphic response to extreme rainfall in headwater systems: Flash floods and debris flows, J. Hydrol., 518, 194-205, https://doi.org/10.1016/j.jhydrol.2014.05.022, 2014.

Cassola, F., Ferrari, F., and Mazzino, A.: Numerical simulations of Mediterranean heavy precipitation events with the WRF model: A verification exercise using different approaches, Atmos. Res., 164-165, 210-225, https://doi.org/10.1016/j.atmosres.2015.05.010, 2015.

Chan, S. C., Kendon, E. J., Roberts, N., Blenkinsop, S., and Fowler, H. J.: Large-scale predictors for extreme hourly precipitation events in convection-permitting climate simulations, J. Climate, 31, 2115-2131, https://doi.org/10.1175/JCLI-D-170404.1, 2018.

Ciach, G. J. and Krajewski, W. F.: Analysis and modeling of spatial correlation structure in small-scale rainfall in Central Oklahoma, Adv. Water Resour., 29, 1450-1463, https://doi.org/10.1016/j.advwatres.2005.11.003, 2006.

Collier, C. G.: Flash flood forecasting: What are the limits of predictability?, Q. J. Roy. Meteor. Soc., 133, 3-23, https://doi.org/10.1002/qj.29, 2007.

Cristiano, E., ten Veldhuis, M.-C., and van de Giesen, N.: Spatial and temporal variability of rainfall and their effects on hydrological response in urban areas - a review, Hydrol. Earth Syst. Sci., 21, 3859-3878, https://doi.org/10.5194/hess-21-3859-2017, 2017.

Davis, C., Brown, B., and Bullock, R.: Object-Based Verification of Precipitation Forecasts. Part I: Methodology and Application to Mesoscale Rain Areas, Mon. Weather Rev., 134, 1772-1784, https://doi.org/10.1175/MWR3145.1, 2006.

Dayan, U. and Morin, E.: Flash flood - producing rainstorms over the Dead Sea: A review, New frontiers in Dead Sea paleoenviron- 
mental research: Geological Society of America Special Paper, 401, 53-62, https://doi.org/10.1130/2006.2401(04), 2006.

Dayan, U., Ziv, B., Margalit, A., Morin, E., and Sharon, D.: A severe autumn storm over the Middle-East: Synoptic and mesoscale convection analysis, Theor. Appl. Climatol., 69, 103122, https://doi.org/10.1007/s007040170038, 2001.

Dayan, U., Nissen, K., and Ulbrich, U.: Review Article: Atmospheric conditions inducing extreme precipitation over the eastern and western Mediterranean, Nat. Hazards Earth Syst. Sci., 15, 2525-2544, https://doi.org/10.5194/nhess-15-2525-2015, 2015.

Dee, D. P., Uppala, S. M., Simmons, A. J., Berrisford, P., Poli, P., Kobayashi, S., Andrae, U., Balmaseda, M. A., Balsamo, G., Bauer, P., Bechtold, P., Beljaars, A. C. M., van de Berg, L., Bidlot, J., Bormann, N., Delsol, C., Dragani, R., Fuentes, M., Geer, A. J., Haimberger, L., Healy, S. B., Hersbach, H., Hólm, E. V., Isaksen, L., Kållberg, P., Köhler, M., Matricardi, M., McNally, A. P., Monge-Sanz, B. M., Morcrette, J.-J., Park, B.-K., Peubey, C., de Rosnay, P., Tavolato, C., Thépaut, J.-N., and Vitart, F.: The ERA-Interim reanalysis: configuration and performance of the data assimilation system, Q. J. Roy. Meteor. Soc., 137, 553-597, https://doi.org/10.1002/qj.828, 2011.

Deng, L., McCabe, M. F., Stenchikov, G., Evans, J. P., and Kucera, P. a.: Simulation of Flash-Flood-Producing Storm Events in Saudi Arabia Using the Weather Research and Forecasting Model, J. Hydrometeorol., 16, 615-630, https://doi.org/10.1175/JHM-D-14-0126.1, 2015.

De Vries, A. J., Tyrlis, E., Edry, D., Krichak, S. O., Steil, B., and Lelieveld, J.: Extreme precipitation events in the Middle East: Dynamics of the Active Red Sea Trough, J. Geophys. Res.Atmos., 118, 7087-7108, https://doi.org/10.1002/jgrd.50569, 2013.

Diomede, T., Marsigli, C., Montani, A., Nerozzi, F., and Paccagnella, T.: Calibration of limited-area ensemble precipitation forecasts for hydrological predictions, Mon. Weather Rev., 142, 2176-2197, https://doi.org/10.1175/MWR-D-13-00071.1, 2014.

Doswell, C. A., Brooks, H. E., and Maddox, R. A.: Flash Flood Forecasting: An Ingredients-Based Methodology, Weather Forecast., 11, 560-581, https://doi.org/10.1175/15200434(1996)011<0560:FFFAIB > 2.0.CO;2, 1996.

Drobinski, P., Ducrocq, V., Alpert, P., Anagnostou, E., Béranger, K., Borga, M., Braud, I., Chanzy, A., Davolio, S., Delrieu, G., Estournel, C., Boubrahmi, N. F., Font, J., Grubišić, V., Gualdi, S., Homar, V., Ivančan-Picek, B., Kottmeier, C., Kotroni, V., Lagouvardos, K., Lionello, P., Llasat, M. C., Ludwig, W., Lutoff, C., Mariotti, A., Richard, E., Romero, R., Rotunno, R., Roussot, O., Ruin, I., Somot, S., Taupier-Letage, I., Tintore, J., Uijlenhoet, R., and Wernli, H.: HyMeX: A 10-Year Multidisciplinary Program on the Mediterranean Water Cycle, B. Am. Meteorol. Soc., 95, 1063-1082, https://doi.org/10.1175/BAMS-D-12$00242.1,2014$.

Durrans, S. R., Julian, L. T., and Yekta, M.: Estimation of Depth-Area Relationships using Radar-Rainfall Data, J. Hydrol. Eng., 7, 356-367, https://doi.org/10.1061/(ASCE)10840699(2002)7:5(356), 2002.

Easterling, D. R., Evans, J. L., Groisman, P. Y., Karl, T. R., Kunkel, K. E., and Ambenje, P.: Observed variability and trends in extreme climate events: A brief review, B. Am.
Meteorol. Soc., 81, 417-425, https://doi.org/10.1175/15200477(2000)081<0417:OVATIE>2.3.CO;2, 2000.

El-Samra, R., Bou-Zeid, E., and El-Fadel, M.: To what extent does high-resolution dynamical downscaling improve the representation of climatic extremes over an orographically complex terrain?, Theor. Appl. Climatol., 134, 265-282, https://doi.org/10.1007/s00704-017-2273-8, 2018.

EMS Mekorot Projects Ltd: Rainfall data from a C-band weather radar, http://www.emsmekorotprojects.com/, last access: May 2019.

Enzel, Y., Amit, R., Dayan, U., Crouvi, O., Kahana, R., Ziv, B., and Sharon, D.: The climatic and physiographic controls of the eastern Mediterranean over the late Pleistocene climates in the southern Levant and its neighboring deserts, Global Planet. Change, 60, 165-192, https://doi.org/10.1016/j.gloplacha.2007.02.003, 2008.

European Centre for Medium-Range Weather Forecasts: ERAInterim Project, Single Parameter 6-Hourly Surface Analysis and Surface Forecast Time Series, updated monthly, https://doi.org/10.5065/D64747WN, 2012.

Farhan, Y. and Anbar, A.: Fragile Landscape : Impact and Consequences of May 2014 Flash-flood Disaster in the Aqaba Area, Southern Jordan, Research Journal of Environmental and Earth Sciences, 6, 451-465, 2014.

Flaounas, E., Kotroni, V., Lagouvardos, K., Gray, S. L., Rysman, J. F., and Claud, C.: Heavy rainfall in Mediterranean cyclones. Part I: contribution of deep convection and warm conveyor belt, Clim. Dynam., 50, 2935-2949, https://doi.org/10.1007/s00382017-3783-x, 2018.

Flaounas, E., Fita, L., Lagouvardos, K., and Kotroni, V.: Heavy rainfall in Mediterranean cyclones, Part II: Water budget, precipitation efficiency and remote water sources, Clim. Dynam., 53, 2539-2555, https://doi.org/10.1007/s00382-019-04639-x, 2019.

Fosser, G., Khodayar, S., and Berg, P.: Benefit of convection permitting climate model simulations in the representation of convective precipitation, Clim. Dynam., 44, 45-60, https://doi.org/10.1007/s00382-014-2242-1, 2014.

Gamo, M.: Thickness of the dry convection and large-scale subsidence above deserts, Bound.-Lay. Meteorol., 79, 265-278, https://doi.org/10.1007/BF00119441, 1996.

Gehne, M., Hamill, T. M., Kiladis, G. N., and Trenberth, K. E.: Comparison of global precipitation estimates across a range of temporal and spatial scales, J. Climate, 29, 7773-7795, https://doi.org/10.1175/JCLI-D-15-0618.1, 2016.

Gilleland, E., Ahijevych, D., Brown, B. G., Casati, B., and Ebert, E. E.: Intercomparison of Spatial Forecast Verification Methods, Weather Forecast., 24, 1416-1430, https://doi.org/10.1175/2009WAF2222269.1, 2009.

Giorgi, F. and Lionello, P.: Climate change projections for the Mediterranean region, Global Planet. Change, 63, 90-104, https://doi.org/10.1016/j.gloplacha.2007.09.005, 2008.

Goldreich, Y.: The spatial distribution of annual rainfall in Israel - a review, Theor. Appl. Climatol., 50, 45-59, https://doi.org/10.1007/BF00864902, 1994.

Goldreich, Y.: The climate of Israel: observation, research and application, Springer Science \& Business Media, https://doi.org/10.1007/978-1-4615-0697-3, 2012.

Goldreich, Y., Mozes, H., and Rosenfeld, D.: Radar analysis of cloud systems and their rainfall yield in Israel, Israel J. Earth Sci., 
53, 63-76, https://doi.org/10.1560/G68K-30MN-D5V0-KUHU, 2004.

Gómez-Navarro, J. J., Raible, C. C., García-Valero, J. A., Messmer, M., Montávez, J. P., and Martius, O.: Event selection for dynamical downscaling: a neural network approach for physically-constrained precipitation events, Clim. Dynam., https://doi.org/10.1007/s00382-019-04818-w, 2019.

Gustafsson, N., Janjić, T., Schraff, C., Leuenberger, D., Weissmann, M., Reich, H., Brousseau, P., Montmerle, T., Wattrelot, E., Bučánek, A., Mile, M., Hamdi, R., Lindskog, M., Barkmeijer, J., Dahlbom, M., Macpherson, B., Ballard, S., Inverarity, G., Carley, J., Alexander, C., Dowell, D., Liu, S., Ikuta, Y., and Fujita, T.: Survey of data assimilation methods for convective-scale numerical weather prediction at operational centres, Q. J. Roy. Meteor. Soc., 144, 1218-1256, https://doi.org/10.1002/qj.3179, 2018.

Hahmann, A. N., Rostkier-Edelstein, D., Warner, T. T., Vandenberghe, F., Liu, Y., Babarsky, R., and Swerdlin, S. P.: A reanalysis system for the generation of mesoscale climatographies, J. Appl. Meteorol. Clim., 49, 954-972, https://doi.org/10.1175/2009JAMC2351.1, 2010.

Hamill, T. M., Hagedorn, R., and Whitaker, J. S.: Probabilistic forecast calibration using ECMWF and GFS ensemble reforecasts. Part II: Precipitation, Mon. Weather Rev., 136, 2620-2632, https://doi.org/10.1175/2007MWR2411.1, 2008.

Hersbach, H.: The ERA5 Atmospheric Reanalysis, AGU Fall Meeting Abstracts, December 2016, San Francisco, USA, 2016.

Hochman, A., Harpaz, T., Saaroni, H., and Alpert, P.: The seasons' length in 21st century CMIP5 projections over the eastern Mediterranean, Int. J. Climatol., 38, 2627-2637, https://doi.org/10.1002/joc.5448, 2018a.

Hochman, A., Mercogliano, P., Alpert, P., Saaroni, H., and Bucchignani, E.: High-resolution projection of climate change and extremity over Israel using COSMO-CLM, Int. J. Climatol., 38, 5095-5106, https://doi.org/10.1002/joc.5714, 2018b.

Hochman, A., Kunin, P., Alpert, P., Harpaz, T., Saaroni, H., and Rostkier-Edelstein, D.: Statistical downscaling of seasonal precipitation over Israel for the 21st century, using CMIP5 projections, Int. J. Climatol., 40, 2062-2077, 2020.

Iacono, M. J., Delamere, J. S., Mlawer, E. J., Shephard, M. W., Clough, S. A., and Collins, W. D.: Radiative forcing by longlived greenhouse gases: Calculations with the AER radiative transfer models, J. Geophys. Res.-Atmos., 113, D13103, https://doi.org/10.1029/2008JD009944, 2008.

Ivatek-Šahdan, S., Stanešić, A., Tudor, M., Odak Plenković, I., and Janeković, I.: Impact of SST on heavy rainfall events on eastern Adriatic during SOP1 of HyMeX, Atmos. Res., 200, 36-59, https://doi.org/10.1016/j.atmosres.2017.09.019, 2018.

Janjić, Z. I.: The Step-Mountain Eta Coordinate Model: Further Developments of the Convection, Viscous Sublayer, and Turbulence Closure Schemes, Mon. Weather Rev., 122, 927-945, https://doi.org/10.1175/15200493(1994)122<0927:TSMECM>2.0.CO;2, 1994.

Kahana, R., Ziv, B., Enzel, Y., and Dayan, U.: Synoptic climatology of major floods in the Negev Desert, Israel, Int. J. Climatol., 22, 867-882, https://doi.org/10.1002/joc.766, 2002.

Kalma, J. D. and Franks, S. W.: Rainfall in arid and semi-arid regions, in: Understanding Water in a Dry Environment, edited by:
Simmers, I., chap. 2, 15-64, Taylor \& Francis, Lisse, the Netherlands, 2003.

Karklinsky, M. and Morin, E.: Spatial characteristics of radarderived convective rain cells over southern Israel, Meteorol. Z., 15, 513-520, https://doi.org/10.1127/0941-2948/2006/0153, 2006.

Keil, C., Heinlein, F., and Craig, G. C.: The convective adjustment time-scale as indicator of predictability of convective precipitation, Q. J. Roy. Meteor. Soc., 140, 480-490, https://doi.org/10.1002/qj.2143, 2014.

Kelley, C. P., Mohtadi, S., Cane, M. A., Seager, R., and Kushnir, Y.: Climate change in the Fertile Crescent and implications of the recent Syrian drought, P. Natl. Acad. Sci. USA, 112, 3241-3246, https://doi.org/10.1073/pnas.1421533112, 2015.

Kendon, E. J., Roberts, N. M., Fowler, H. J., Roberts, M. J., Chan, S. C., and Senior, C. A.: Heavier summer downpours with climate change revealed by weather forecast resolution model, Nat. Clim. Change, 4, 570-576, https://doi.org/10.1038/nclimate2258, 2014.

Khodayar, S., Fosser, G., Berthou, S., Davolio, S., Drobinski, P., Ducrocq, V., Ferretti, R., Nuret, M., Pichelli, E., Richard, E., and Bock, O.: A seamless weather-climate multi-model intercomparison on the representation of a high impact weather event in the western Mediterranean: HyMeX IOP12, Q. J. Roy. Meteor. Soc., 142, 433-452, https://doi.org/10.1002/qj.2700, 2016.

Khodayar, S., Kalthoff, N., and Kottmeier, C.: Atmospheric conditions associated with heavy precipitation events in comparison to seasonal means in the western mediterranean region, Clim. Dynam., 51, 951-967, https://doi.org/10.1007/s00382-016-3058-y, 2018.

Kidd, C., Becker, A., Huffman, G. J., Muller, C. L., Joe, P., Skofronick-Jackson, G., and Kirschbaum, D. B.: So, how much of the Earth's surface is covered by rain gauges?, B. Am. Meteorol. Soc., 98, 69-78, https://doi.org/10.1175/BAMS-D-1400283.1, 2017.

Krichak, S. O., Alpert, P., and Krishnamurti, T. N.: Interaction of topography and tropospheric flow - A possible generator for the Red Sea Trough?, Meteorol. Atmos. Phys., 63, 149-158, https://doi.org/10.1007/BF01027381, 1997.

Krichak, S. O., Tsidulko, M., and Alpert, P.: November 2, 1994, severe storms in the southeastern Mediterranean, Atmos. Res., 53, 45-62, https://doi.org/10.1016/S0169-8095(99)00045-9, 2000.

Kushnir, Y., Dayan, U., Ziv, B., Morin, E., and Enzel, Y.: Climate of the Levant: phenomena and mechanisms, in: Quaternary of the Levant: environments, climate change, and humans, edited by: Enzel, Y. and Ofer, B.-Y., chap. 4, 31-44, Cambridge University Press, Cambridge, UK, 2017.

Maraun, D., Wetterhall, F., Chandler, R. E., Kendon, E. J., Widmann, M., Brienen, S., Rust, H. W., Sauter, T., Themeßl, M., Venema, V. K. C., Chun, K. P., Goodess, C. M., Jones, R. G., Onof, C., Vrac, M., and Thiele-Eich, I.: Precipitation downscaling under climate change: Recent developements to bridge the gap between dynamical models and the end user, Rev. Geophys., 48, RG3003, https://doi.org/10.1029/2009RG000314, 2010.

Marra, F. and Morin, E.: Use of radar QPE for the derivation of Intensity-Duration-Frequency curves in a range of climatic regimes, J. Hydrol., 531, 427-440, https://doi.org/10.1016/j.jhydrol.2015.08.064, 2015. 
Marra, F. and Morin, E.: Autocorrelation structure of convective rainfall in semiarid-arid climate derived from highresolution X-Band radar estimates, Atmos. Res., 200, 126-138, https://doi.org/10.1016/j.atmosres.2017.09.020, 2018.

Marra, F., Morin, E., Peleg, N., Mei, Y., and Anagnostou, E. N.: Intensity-duration-frequency curves from remote sensing rainfall estimates: comparing satellite and weather radar over the eastern Mediterranean, Hydrol. Earth Syst. Sci., 21, 2389-2404, https://doi.org/10.5194/hess-21-2389-2017, 2017.

Marra, F., Zoccatelli, D., Armon, M., and Morin, E.: A simplified MEV formulation to model extremes emerging from multiple nonstationary underlying processes, Adv. Water Resour., 127, 280-290, https://doi.org/10.1016/j.advwatres.2019.04.002, 2019.

Marsham, J. H., Hobby, M., Allen, C. J. T., Banks, J. R., Bart, M., Brooks, B. J., Cavazos-Guerra, C., Engelstaedter, S., Gascoyne, M., Lima, A. R., Martins, J. V., McQuaid, J. B., O'Leary, A., Ouchene, B., Ouladichir, A., Parker, D. J., Saci, A., Salah-Ferroudj, M., Todd, M. C., and Washington, R.: Meteorology and dust in the central Sahara: Observations from Fennec supersite-1 during the June 2011 Intensive Observation Period, J. Geophys. Res.-Atmos., 118, 4069-4089, https://doi.org/10.1002/jgrd.50211, 2013.

Mass, C. F., Ovens, D., Westrick, K., and Colle, B. A.: Does Increasing Horizontal Resolution Produce More Skillful Forecasts?, B. Am. Meteorol. Soc., 83, 407-430, https://doi.org/10.1175/15200477(2002)083<0407:DIHRPM>2.3.CO;2, 2002.

Menne, M. J., Durre, I., Korzeniewski, B., McNeal, S., Thomas, K., Yin, X., Anthony, S., Ray, R., Vose, R. S., Gleason, B. E., and Houston, T. G.: Global Historical Climatology Network Daily (GHCN-Daily), Version 3, NOAA National Climatic Data Center, https://doi.org/10.7289/V5D21VHZ, 2012.

Meredith, E. P., Rust, H. W., and Ulbrich, U.: A classification algorithm for selective dynamical downscaling of precipitation extremes, Hydrol. Earth Syst. Sci., 22, 4183-4200, https://doi.org/10.5194/hess-22-4183-2018, 2018.

Merz, R. and Blöschl, G.: A process typology of regional floods, Water Resour. Res., 39, 1-20, https://doi.org/10.1029/2002WR001952, 2003.

Morin, E., Krajewski, W. F., Goodrich, D. C., Gao, X., and Sorooshian, S.: Estimating Rainfall Intensities from Weather Radar Data: The Scale-Dependency Problem, J. Hydrometeorol., 4, 782-797, https://doi.org/10.1175/15257541(2003)004<0782:ERIFWR>2.0.CO;2, 2003.

Morin, E., Harats, N., Jacoby, Y., Arbel, S., Getker, M., Arazi, A., Grodek, T., Ziv, B., and Dayan, U.: Studying the extremes: hydrometeorological investigation of a floodcausing rainstorm over Israel, Adv. Geosci., 12, 107-114, https://doi.org/10.5194/adgeo-12-107-2007, 2007.

Morin, E., Jacoby, Y., Navon, S., and Bet-Halachmi, E.: Towards flash-flood prediction in the dry Dead Sea region utilizing radar rainfall information, Adv. Water Resour., 32, 1066-1076, https://doi.org/10.1016/j.advwatres.2008.11.011, 2009.

Morin, E., Marra, F., and Armon, M.: Dryland Precipitation Climatology from Satellite Observations, in: Satellite Precipitation Measurement, edited by: Levizzani, V., Kidd, C., Kirschbaum, D., Kummerow, C., and Turk, F. J., Springer, Heidelberg, Germany, 2020 .
Nasta, P., Adane, Z., Lock, N., Houston, A., and Gates, J. B.: Links between episodic groundwater recharge rates and rainfall events classified according to stratiform-convective storm scoring: A plot-scale study in eastern Nebraska, Agr. Forest Meteorol., 259, 154-161, https://doi.org/10.1016/j.agrformet.2018.05.003, 2018.

Nerini, D., Besic, N., Sideris, I., Germann, U., and Foresti, L.: A non-stationary stochastic ensemble generator for radar rainfall fields based on the short-space Fourier transform, Hydrol. Earth Syst. Sci., 21, 2777-2797, https://doi.org/10.5194/hess-21-27772017, 2017.

Nicholson, S. E.: Dryland climatology, Cambridge University Press, New York, https://doi.org/10.1017/CBO9780511973840, 2011.

Nuissier, O., Joly, B., Joly, A., Ducrocq, V., and Arbogast, P.: A statistical downscaling to identify the large-scale circulation patterns associated with heavy precipitation events over southern France, Q. J. Roy. Meteor. Soc., 137, 1812-1827, https://doi.org/10.1002/qj.866, 2011.

Panziera, L., James, C. N., and Germann, U.: Mesoscale organization and structure of orographic precipitation producing flash floods in the Lago Maggiore region, Q. J. Roy. Meteor. Soc., 141, 224-248, https://doi.org/10.1002/qj.2351, 2015.

Panziera, L., Gabella, M., Germann, U., and Martius, O.: A 12-year radar-based climatology of daily and sub-daily extreme precipitation over the Swiss Alps, Int. J. Climatol., 38, 3749-3769, https://doi.org/10.1002/joc.5528, 2018.

Pastor, F., Estrela, M. J., Peñarrocha, D., and Millán, M. M.: Torrential Rains on the Spanish Mediterranean Coast: Modeling the Effects of the Sea Surface Temperature, J. Appl. Meteorol., 40, 1180-1195, https://doi.org/10.1175/15200450(2001)040<1180:trotsm>2.0.co;2, 2002.

Peleg, N. and Morin, E.: Convective rain cells: Radar-derived spatiotemporal characteristics and synoptic patterns over the eastern Mediterranean, J. Geophys. Res.-Atmos., 117, 1-17, https://doi.org/10.1029/2011JD017353, 2012.

Peleg, N., Marra, F., Fatichi, S., Molnar, P., Morin, E., Sharma, A., and Burlando, P.: Intensification of convective rain cells at warmer temperatures observed from highresolution weather radar data, J. Hydrometeorol., 19, 715-726, https://doi.org/10.1175/JHM-D-17-0158.1, 2018.

Prein, A. F., Langhans, W., Fosser, G., Ferrone, A., Ban, N., Goergen, K., Keller, M., Tölle, M., Gutjahr, O., Feser, F., Brisson, E., Kollet, S., Schmidli, J., Van Lipzig, N. P., and Leung, R.: A review on regional convection-permitting climate modeling: Demonstrations, prospects, and challenges, Rev. Geophys., 53, 323-361, https://doi.org/10.1002/2014RG000475, 2015.

Raveh-Rubin, S. and Wernli, H.: Large-scale wind and precipitation extremes in the Mediterranean: a climatological analysis for 1979-2012, Q. J. Roy. Meteor. Soc., 141, 2404-2417, https://doi.org/10.1002/qj.2531, 2015.

Rinat, Y., Marra, F., Zoccatelli, D., and Morin, E.: Controls of flash flood peak discharge in Mediterranean basins and the special role of runoff-contributing areas, J. Hydrol., 565, 846-860, https://doi.org/10.1016/j.jhydrol.2018.08.055, 2018.

Roberts, N.: Assessing the spatial and temporal variation in the skill of precipitation forecasts from an NWP model, Meteorol. Appl., 15, 163-169, https://doi.org/10.1002/met.57, 2008.

Roberts, N. M. and Lean, H. W.: Scale-Selective Verification of Rainfall Accumulations from High-Resolution Fore- 
casts of Convective Events, Mon. Weather Rev., 136, 78-97, https://doi.org/10.1175/2007MWR2123.1, 2008.

Romine, G. S., Schwartz, C. S., Snyder, C., Anderson, J. L., and Weisman, M. L.: Model Bias in a Continuously Cycled Assimilation System and Its Influence on ConvectionPermitting Forecasts, Mon. Weather Rev., 141, 1263-1284, https://doi.org/10.1175/MWR-D-12-00112.1, 2013.

Rostkier-Edelstein, D., Liu, Y., Wu, W., Kunin, P., Givati, A., and Ge, M.: Towards a high-resolution climatography of seasonal precipitation over Israel, Int. J. Climatol., 34, 1964-1979, https://doi.org/10.1002/joc.3814, 2014.

Rostkier-Edelstein, D., Kunin, P., Hopson, T. M., and Givati, A.: Statistical downscaling of seasonal precipitation in Israel, Int. J. Climatol., 36, 590-606, https://doi.org/10.1002/joc.4368, 2015.

Rubin, S., Ziv, B., and Paldor, N.: Tropical Plumes over Eastern North Africa as a Source of Rain in the Middle East, Mon. Weather Rev., 135, 4135-4148, https://doi.org/10.1175/2007MWR1919.1, 2007.

Saaroni, H., Halfon, N., Ziv, B., Alpert, P., and Kutiel, H.: Links between the rainfall regime in Israel and location and intensity of Cyprus lows, Int. J. Climatol., 30, 1014-1025, https://doi.org/10.1002/joc.1912, 2010.

Saaroni, H., Ziv, B., Lempert, J., Gazit, Y., and Morin, E.: Prolonged dry spells in the Levant region: Climatologicsynoptic analysis, Int. J. Climatol., 2236, 2223-2236, https://doi.org/10.1002/joc.4143, 2014.

Saltikoff, E., Friedrich, K., Soderholm, J., Lengfeld, K., Nelson, B., Becker, A., Hollmann, R., Urban, B., Heistermann, M., and Tassone, C.: An overview of using weather radar for climatological studies: Successes, challenges and potential., B. Am. Meteorol. Soc., 100, 1739-1752, https://doi.org/10.1175/bams-d-180166.1, 2019.

Samuels, R., Rimmer, A., and Alpert, P.: Effect of extreme rainfall events on the water resources of the Jordan River, J. Hydrol., 375, 513-523, https://doi.org/10.1016/j.jhydrol.2009.07.001, 2009.

Schär, C., Ban, N., Fischer, E. M., Rajczak, J., Schmidli, J., Frei, C., Giorgi, F., Karl, T. R., Kendon, E. J., Tank, A. M., O’Gorman, P. A., Sillmann, J., Zhang, X., and Zwiers, F. W.: Percentile indices for assessing changes in heavy precipitation events, Climatic Change, 137, 201-216, https://doi.org/10.1007/s10584016-1669-2, 2016.

Schick, A. P.: Hydrologic aspects of floods in extreme arid environments, in: Flood geomorphology, edited by: Baker, V. R., Kochel, R. C., and Patton, P. C., chap. 12, 189-203, John Wiley and Sons, New York, USA, 1988.

Schwartz, C. S., Romine, G. S., Sobash, R. A., Fossell, K. R., and Weisman, M. L.: NCAR's Experimental Real-Time ConvectionAllowing Ensemble Prediction System, Weather Forecast., 30, 1645-1654, https://doi.org/10.1175/WAF-D-15-0103.1, 2015.

Seager, R., Liu, H., Henderson, N., Simpson, I., Kelley, C., Shaw, T., Kushnir, Y., and Ting, M.: Causes of increasing aridification of the mediterranean region in response to rising greenhouse gases, J. Climate, 27, 4655-4676, https://doi.org/10.1175/JCLI-D-1300446.1, 2014.

Sharon, D.: The spottiness of rainfall in a desert area, J. Hydrol., 17, 161-175, https://doi.org/10.1016/0022-1694(72)90002-9, 1972.

Sharon, D. and Kutiel, H.: The distribution of rainfall intensity in Israel, its regional and seasonal variations and its climatological evaluation, J. Climatol., 6, 277-291, https://doi.org/10.1002/joc.3370060304, 1986.

Skamarock, W. C., Klemp, J. B., Dudhia, J., Gill, D. O., Barker, D. M., Duda, M. G., Huang, X. Y., Wang, W., and Powers, J. G.: A Description of the Advanced Research WRF Version 3, https://doi.org/10.5065/D68S4MVH, 2008.

Smith, J. A., Baeck, M. L., Zhang, Y., and Doswell, C. A.: Extreme Rainfall and Flooding from Supercell Thunderstorms, J. Hydrometeorol., 2, 469-489, https://doi.org/10.1175/15257541(2001)002<0469:ERAFFS>2.0.CO;2, 2001.

Smith, J. A., Baeck, M. L., Villarini, G., Welty, C., Miller, A. J., and Krajewski, W. F.: Analyses of a long-term, high-resolution radar rainfall data set for the Baltimore metropolitan region, Water Resour. Res., 48, 1-14, https://doi.org/10.1029/2011WR010641, 2012.

Sowers, J., Vengosh, A., and Weinthal, E.: Climate change, water resources, and the politics of adaptation in the Middle East and North Africa, Climatic Change, 104, 599-627, https://doi.org/10.1007/s10584-010-9835-4, 2010.

Tarolli, P., Borga, M., Morin, E., and Delrieu, G.: Analysis of flash flood regimes in the North-Western and South-Eastern Mediterranean regions, Nat. Hazards Earth Syst. Sci., 12, 1255-1265, https://doi.org/10.5194/nhess-12-1255-2012, 2012.

Taylor, R. G., Todd, M. C., Kongola, L., Maurice, L., Nahozya, E., Sanga, H., and Macdonald, A. M.: Evidence of the dependence of groundwater resources on extreme rainfall in East Africa, Nat. Clim. Change, 3, 374-378, https://doi.org/10.1038/nclimate1731, 2013.

Tewari, M., Chen, F., Wang, W., Dudhia, J., LeMone, M. A., Mitchell, K., Ek, M., Gayno, G., Wegiel, J., and Cuenca, R. H.: Implementation and verification of the unified NOAH land surface model in the WRF model (Formerly Paper Number 17.5), in: 20th Conference on Weather Analysis and Forecasting/16th Conference on Numerical Weather Prediction, January 2004, Seattle, Washington, USA, 11-15, 2004.

Thompson, G., Field, P. R., Rasmussen, R. M., and Hall, W. D.: Explicit Forecasts of Winter Precipitation Using an Improved Bulk Microphysics Scheme. Part II: Implementation of a New Snow Parameterization, Mon. Weather Rev., 136, 5095-5115, https://doi.org/10.1175/2008MWR2387.1, 2008.

Thorndahl, S., Smith, J. A., Baeck, M. L., and Krajewski, W. F.: Analyses of the temporal and spatial structures of heavy rainfall from a catalog of highresolution radar rainfall fields, Atmos. Res., 144, 111-125, https://doi.org/10.1016/j.atmosres.2014.03.013, 2014.

Tiedtke, M.: A Comprehensive Mass Flux Scheme for $\mathrm{Cu}$ mulus Parameterization in Large-Scale Models, Mon Weather Rev., 117, 1779-1800, https://doi.org/10.1175/15200493(1989)117<1779:ACMFSF>2.0.CO;2, 1989.

Trenberth, K. E., Dai, A., Rasmussen, R. M., and Parsons, D. B.: The changing character of precipitation, B. Am. Meteorol Soc., 84, 1205-1218, https://doi.org/10.1175/BAMS-84-9-1205, 2003.

Tubi, A., Dayan, U., and Lensky, I. M.: Moisture transport by tropical plumes over the Middle East: a 30-year climatology, Q. J. Roy. Meteor. Soc., 143, 3165-3176, https://doi.org/10.1002/qj.3170, 2017.

UN-Habitat: Cities and Climate Change: Global Report on Human Settlements 2011, Tech. rep., London \& Wash- 
ington, D.C., available at: http://books.google.com/books? $\mathrm{hl}=$ en\&lr=\&id=GZG5x6SbeSAC\&oi=fnd\&pg=PA91\& $\mathrm{dq}=$ Cities+and+Climate + Change\&ots=adeiArrg6X\&sig= 9TeIo2HeRHPqS1KwBKsvkC78Afg (last access: May 2019), 2011.

Villarini, G., Mandapaka, P. V., Krajewski, W. F., and Moore, R. J.: Rainfall and sampling uncertainties: A rain gauge perspective, J. Geophys. Res.-Atmos., 113, 1-12, https://doi.org/10.1029/2007JD009214, 2008.

Vincendon, B., Ducrocq, V., Nuissier, O., and Vié, B.: Perturbation of convection-permitting NWP forecasts for flash-flood ensemble forecasting, Nat. Hazards Earth Syst. Sci., 11, 1529-1544, https://doi.org/10.5194/nhess-11-1529-2011, 2011.

Warner, T. T.: Desert Meteorology, Cambridge University Press, New York, https://doi.org/10.1256/wea.201.04, 2004.

Warner, T. T.: Numerical Weather and Climate Prediction, Cambridge University Press, Cambridge, UK, https://doi.org/10.1017/CBO9780511763243, 2010.

Wernli, H., Paulat, M., Hagen, M., and Frei, C.: SAL-A Novel Quality Measure for the Verification of Quantitative Precipitation Forecasts, Mon. Weather Rev., 136, 4470-4487, https://doi.org/10.1175/2008MWR2415.1, 2008.

Wernli, H., Hofmann, C., and Zimmer, M.: Spatial Forecast Verification Methods Intercomparison Project: Application of the SAL Technique, Weather Forecast., 24, 1472-1484, https://doi.org/10.1175/2009WAF2222271.1, 2009.

Westra, S., Fowler, H. J., Evans, J. P., Alexander, L. V., Berg, P., Johnson, F., Kendon, E. J., Lenderink, G., and Roberts, N. M.: Future changes to the intensity and frequency of short-duration extreme rainfall, Rev. Geophys., 52, 522-555, https://doi.org/10.1002/2014RG000464, 2014.

Yang, L., Smith, J. A., Baeck, M. L., Bou-Zeid, E., Jessup, S. M., Tian, F., and Hu, H.: Impact of Urbanization on Heavy Convective Precipitation under Strong Large-Scale Forcing: A Case Study over the Milwaukee-Lake Michigan Region, J. Hydrometeorol., 15, 261-278, https://doi.org/10.1175/JHM-D-13-020.1, 2014.

Yano, J. I. I., Ziemian`ski, M. Z., Cullen, M., Termonia, P., Onvlee, J., Bengtsson, L., Carrassi, A., Davy, R., Deluca, A., Gray, S. L., Homar, V., Köhler, M. I., Krichak, S., Michaelides, S., Phillips, V. T., Soares, P. M., and Wyszogrodzki, A. A.: Scientific challenges of convective-scale numerical weather prediction, B. Am. Meteorol. Soc., 99, 699-710, https://doi.org/10.1175/BAMS-D17-0125.1, 2018.
Zepeda-Arce, J., Foufoula-Georgiou, E., and Droegemeier, K. K.: Space-time rainfall organization and its role in validating quantitative precipitation forecasts, J. Geophys. Res.-Atmos., 105, 10129-10146, https://doi.org/10.1029/1999JD901087, 2000.

Zhang, C., Wang, Y., and Hamilton, K.: Improved Representation of Boundary Layer Clouds over the Southeast Pacific in ARW-WRF Using a Modified Tiedtke Cumulus Parameterization Scheme, Mon. Weather Rev., 139, 3489-3513, https://doi.org/10.1175/MWR-D-10-05091.1, 2011.

Zhang, F., Bei, N., Rotunno, R., Snyder, C., and Epifanio, C. C.: Mesoscale Predictability of Moist Baroclinic Waves: Convection-Permitting Experiments and Multistage Error Growth Dynamics, J. Atmos. Sci., 64, 3579-3594, https://doi.org/10.1175/JAS4028.1, 2007.

Zhang, X., Alexander, L., Hegerl, G. C., Jones, P., Tank, A. K., Peterson, T. C., Trewin, B., and Zwiers, F. W.: Indices for monitoring changes in extremes based on daily temperature and precipitation data, WIRES Clim. Change, 2, 851-870, https://doi.org/10.1002/wcc.147, 2011.

Zittis, G., Bruggeman, A., Camera, C., Hadjinicolaou, P., and Lelieveld, J.: The added value of convection permitting simulations of extreme precipitation events over the eastern Mediterranean, Atmos. Res., 191, 20-33, https://doi.org/10.1016/j.atmosres.2017.03.002, 2017.

Ziv, B., Harpaz, T., Saaroni, H., and Blender, R.: A new methodology for identifying daughter cyclogenesis: application for the Mediterranean Basin, Int. J. Climatol., 35, 3847-3861, https://doi.org/10.1002/joc.4250, 2015.

Zoccatelli, D., Marra, F., Armon, M., Rinat, Y., Smith, J. A., and Morin, E.: Contrasting rainfall-runoff characteristics of floods in desert and Mediterranean basins, Hydrol. Earth Syst. Sci., 23, 2665-2678, https://doi.org/10.5194/hess-23-2665-2019, 2019. 